\title{
In Search of Panacea-Review of Recent Studies Concerning Nature-Derived Anticancer Agents
}

\author{
Dawid Przystupski ${ }^{1, *}$, Magdalena J. Niemczura ${ }^{2}$, Agata Górska ${ }^{2}$, Stanisław Supplitt ${ }^{1}$, \\ Krzysztof Kotowski ${ }^{1}$, Piotr Wawryka ${ }^{1}$, Paulina Rozborska ${ }^{3}$, Kinga Woźniak ${ }^{3}$, Olga Michel ${ }^{4}$, \\ Aleksander Kiełbik ${ }^{1}$, Weronika Bartosik ${ }^{5}$, Jolanta Saczko ${ }^{6}$ and Julita Kulbacka ${ }^{6, *(D)}$ \\ 1 Faculty of Medicine, Wroclaw Medical University, J. Mikulicza-Radeckiego 5, 50-345 Wroclaw, Poland; \\ stkwiatek@gmail.com (S.S.); krzysztof.kotowski96@gmail.com (K.K.); piotr95wawryka@gmail.com (P.W.); \\ akielbik6@gmail.com (A.K.) \\ 2 Department of Biological Sciences, Institute of Experimental Biology, University of Wrocław, Kanonia 6/8, \\ 50-328 Wroclaw, Poland; m.j.niemczura@gmail.com (M.J.N.); agata_gorska@onet.eu (A.G.) \\ 3 Faculty of Chemistry, Wroclaw University of Science and Technology, Norwida 4/6, 50-373 Wroclaw, Poland; \\ rozborska.paulina@gmail.com (P.R.); kinga.wozniak@onet.eu (K.W.) \\ 4 Department of Medical Biochemistry, Wroclaw Medical University, Chalubinskiego 10, \\ 50-368 13 Wroclaw, Poland; michel.olga.maria@gmail.com \\ 5 Faculty of Biotechnology, University of Wroclaw, Joliot-Curie 14a, 50-385 Wroclaw, Poland; \\ weronikabartosik@gmail.com \\ 6 Department of Molecular and Cellular Biology, Wroclaw Medical University, Borowska 211A, \\ 50-25 556 Wroclaw, Poland; jolanta.saczko@umed.wroc.pl \\ * Correspondence: dawid.przystupski@gmail.com (D.P.); julita.kulbacka@umed.wroc.pl (J.K.)
}

Received: 1 May 2019; Accepted: 20 June 2019; Published: 25 June 2019

check for updates

\begin{abstract}
Cancers are one of the leading causes of deaths affecting millions of people around the world, therefore they are currently a major public health problem. The treatment of cancer is based on surgical resection, radiotherapy, chemotherapy or immunotherapy, much of which is often insufficient and cause serious, burdensome and undesirable side effects. For many years, assorted secondary metabolites derived from plants have been used as antitumor agents. Recently, researchers have discovered a large number of new natural substances which can effectively interfere with cancer cells' metabolism. The most famous groups of these compounds are topoisomerase and mitotic inhibitors. The aim of the latest research is to characterize natural compounds found in many common foods, especially by means of their abilities to regulate cell cycle, growth and differentiation, as well as epigenetic modulation. In this paper, we focus on a review of recent discoveries regarding nature-derived anticancer agents.
\end{abstract}

Keywords: natural substances; nutraceuticals; phytochemicals; chemoprevention; nutri-epigenetics; anticancer research; mitotic inhibitors; topoisomerase inhibitors; xenobiotics; 6-gingerol; honokiol; polyphenols; drug resistance

\section{Introduction}

Neoplastic disease presents a considerable challenge for current health systems. Proof of this can be seen in increasing trends in annual statistics concerning incidence [1]. Currently applied strategies for cancer treatment are primarily based on surgical resection procedures of the neoplastic mass followed by the introduction of radiotherapy, immunotherapy, and chemotherapy. However, in a significant amount of cases, cancers still present only mediocre clinical response to universal protocols developed for primary tumors or metastases. Furthermore, a considerable amount of anticancer agents carry the risk of various adverse reactions, toxicity and low selectivity for tumor cells [2]. Due to numerous clinical implications 
arising from this phenomena, scientists from all over the world have focused on the search for novel drugs, with special emphasis on implementation of antitumor compounds from natural sources [3].

In the history of anti-cancer therapies, the majority of them have targeted the "hallmarks of cancer," tumor-specific alterations established and described by Hanahan and Weinberg as the following: "sustaining proliferative signaling, evading growth suppressors, resisting cell death, enabling replicative immortality, inducing angiogenesis, activating invasion and metastasis, avoiding immune destruction, cancer-promoting inflammation, genome instability and mutation, and deregulating cellular energetics" [4]. Notably, recent findings regarding molecular mechanisms of carcinogenesis highlighted the importance of genetic and epigenetic alterations as an important issue in cancer prevention and treatment [5-11]. The considerable influence of natural compounds on epigenome has been reported [12], concerning processes associated with carcinogenesis such as histone modifications [13-15] (methylation, acetylation and phosphorylation) which are linked to changes in chromatin structure as well as DNA methylation [16,17] and non-coding microRNA expression [18-20]. Subsequently, those modifications have a broad effect on the expression of target genes, inter alia oncogenes and tumor suppression genes, hence influencing either initiation or progression of cancer.

According to the latest research, the next decade is likely to witness a considerable rise in application of nature-derived compounds exhibiting profound molecular and epigenetic activity as well in clinical cancer therapy routine $[5,7-9,12,14,20-26]$.

The following review summarizes the anticancer activity of well-known substances of natural origin. The agents are specified below in the following order:

1. The mitotic inhibitors:

- Vinca alkaloids-vinblastine, vincristine, vindesine, vinorelbine, vinflunine,

- colchicine,

- podophyllotoxin,

- taxanes (paclitaxel, docetaxel).

2. I and II topoisomerases inhibitors:

- camptothecin,

- topotecan

- irinotecan

- $\quad$ etoposide

3. Inducers of xenobiotic metabolism:

- allyl sulfide,

- indole-3-carbinol,

- phenethyl isothiocyanate,

- sulforaphane,

- glucoraphanin,

- iberin,

- terpenes,

- coumarins.

4. Polyphenols:

- carnosol

- resveratrol

- 6-gingerol,

- honokiol,

- flavonoids. 


\section{Methods}

The selection of articles was conducted on the following databases: Science Direct, Scopus, PubMed, and Google Scholar. Several combinations of the following terms were used: (("natural substances," OR "natural compounds," OR "plant-derived," OR "nature-derived," OR "phytochemicals," OR "nutraceuticals") AND ("cancer," OR "tumor," OR "metastasis") AND ("treatment," OR "anticancer," "prevention," OR "prophylaxis," OR "cell death," OR "drug resistance," OR "cell cycle inhibitors")) within the fields "article title, abstract and keywords." Only articles published in peer-reviewed journals were chosen for the review, preferably written in English. The greatest emphasis was on articles published between 2000 and 2019, however, the specificity of this study required also referring to the earliest reports in the field. In this study, we focused on the anticancer activity of polyphenols and inducers of xenobiotic metabolism as well as natural-derived substances which have widely been used in medicine in recent years.

\section{The Mitotic Inhibitors}

Since microtubules play a significant role in mitosis and cell division, microtubule-targeted antimitotic substances have been involved in cancer therapy, since disrupting mitotic progression significantly slows down the progression of disease [27].

Anti-mitotic drugs can be divided into two major groups: microtubule-destabilizing and microtubule-stabilizing agents. The first group includes compounds such as the Vinca alkaloids (e.g., vinblastine, vincristine, vindesine or vinorelbine), colchicine and podophyllotoxin that inhibits microtubule polymerization at high concentrations. The second group consists of paclitaxel, docetaxel and epothilones which stimulate microtubule polymerization (Table 1) [28].

The antimitotic potential of Vinca alkaloids was discovered in the late 1950s and since then there has been a rapid rise in the use of these compounds in cancer treatment [28]. At high concentrations (e.g., 10-100 nM in HeLa cells) Vinca alkaloids depolymerize microtubules and disrupt mitotic spindles, leading to cell cycle arrest [29]. On the contrary, low but clinically significant concentrations of vinblastine (VBL) (e.g., IC50 $0.8 \mathrm{nM}$ in HeLa cells), do not depolymerize spindle microtubules, but extensively block mitosis leading to cell apoptosis. VBL binds rapidly and reversibly to the $\beta$-subunit of tubulin dimers at a region adjacent to the GTP-binding site, known as the Vinca-binding domain [27]. The binding affinity to microtubules varies among the family of Vinca alkaloids, depending on location of binding sides. Thus, at low concentrations $(<1 \mu \mathrm{mol})$ these compounds bind to the high-affinity sites localized at the microtubule ends. At high concentrations $(>1 \mu \mathrm{mol})$, they tend to bind to low-affinity binding sites along the microtubule surface leading to microtubule depolymerization [30-32]. Outstanding clinical efficacy of VBL as well as its oxidized form, Vincistrine (VCR), applied in several combination therapies, together with the desire to develop orally available analogues, have contributed to the development of various novel semi-synthetic derivatives, including vindesine (VDS), vinorelbine (VRL) and vinflunine (VFL) [33-35] (Table 1).

The risk of side effects and multidrug resistance has slowed down the introduction of Vinca alkaloids for clinical use. To solve these problems, researchers have developed numerous strategies, e.g., using liposomal drug delivery systems [36], chemically modified drugs, and encapsulation in polymeric nanocarriers, to reduce the toxicity and enhance the therapeutic efficiency of Vinca alkaloids [37].

Colchicine, a natural compound isolated from the poisonous meadow saffron Colchicum autumnale L., [33] has been approved for therapy by the U.S Food and Drug Administration (FDA) in 2009 [38] after years of successful application in the treatment of numerous diseases [39-42] (Table 1). The mechanism of action of this compound as well as final effect is quite similar to Vinca alkaloids, namely cell cycle arrest which is caused by depolymerization of the microtubules at high concentrations and stabilizing their dynamics at low concentrations [43]. Colchicine also has the potential to affect intracellular tubulin which leads to restricting mitochondrial metabolism in cancer cells by inhibiting the voltage-dependent anion channels that are located in the mitochondrial membrane [44]. Relatively 
low therapeutic index did not allow the implementation of colchicine in routine cancer treatment [45]. However, studies using nanoparticle-mediated targeted delivery of colchicine shed a new light on this case, allowing the toxic effects of colchicine to be circumvented [46]. Tangutoori et al. (2014) have used Pegylated Cationic Liposomal-colchicine (PCL-colchicine) nanoparticles for in vitro and in vivo studies of lung cancer, and have demonstrated that microtubules are more effectively disrupted by nanoparticle-loaded colchicine than colchicine in natural form. An in vivo study has shown that accumulation of PCL-colchicine in the malignant lung enhanced twofold in comparison to the normal lung, providing longer survival time for the group treated with the PCL-colchicine [47].

Podophyllotoxin (PPT), an aryltetralin lignan naturally occurring in Podophyllum peltatum and L., Podophyllum emodi, that effectively binds to the colchicine-binding side of tubulin from the mitotic spindle, precluding polymerization into microtubules [48]. Due to severely toxic side effects, PPT is unsuitable for clinical use as an antitumor agent [49]. However, in recent decades, a few semi-synthetic derivatives of podophyllotoxin ex etoposide and tenoposide have proven effective in cancer therapy [50]. The mechanism of action of these compounds is based on stabilization of the covalent bond between DNA and topoisomerase II projecting on inhibition of this enzyme, thus preventing the re-ligation of DNA [51].

Table 1. The mitotic inhibitors-a brief summary. Images of the chemical structures obtained from ChemSpider database [52]. $\uparrow:$ upregulation/induction/stimulation, $\downarrow$ : downregulation/inhibition.

\begin{tabular}{|c|c|c|c|c|}
\hline Structure/Name & Mechanism(s) & Experimental Model & Compound Source & Ref. \\
\hline $\begin{array}{l}\text { Vinblastine (above), } \\
\text { vincristine, vindesine, } \\
\text { vinorelbine }\end{array}$ & $\begin{array}{c}\downarrow \text { of microtubule } \\
\text { polymerization, } \\
\uparrow \text { apoptosis, } \\
\uparrow \text { microtubule } \\
\text { depolymerization }\end{array}$ & $\begin{array}{c}\text { HeLa cells, breast and lung cancer, } \\
\text { Hodgkin's disease, } \\
\text { lymphosarcoma, chronic } \\
\text { lymphocytic leukemia, acute } \\
\text { lymphoblastic leukemia, Wilms' } \\
\text { tumor, rhabdo-myosarcoma, } \\
\text { chorio-carcinoma, neuroblastoma }\end{array}$ & $\begin{array}{l}\text { pink periwinkle plant } \\
\text { Catharanthus roseus }\end{array}$ & {$[29,30,33-35,53-55]$} \\
\hline Col & $\begin{array}{c}\downarrow \text { mitosis, } \\
\uparrow \text { microtubules } \\
\text { depolymerization }\end{array}$ & $\begin{array}{l}\text { Due to the low therapeutic index, } \\
\text { currently colchicine is not used } \\
\text { as an anticancer agent }\end{array}$ & $\begin{array}{c}\text { Meadow saffron } \\
\text { Colchicum autumnale L. }\end{array}$ & {$[39-42,45]$} \\
\hline $\begin{array}{l}\text { podophyllotoxin (above), } \\
\text { etoposide and teniposide } \\
\text { (semi-synthetic derivatives } \\
\text { of podophyllotoxin) }\end{array}$ & $\begin{array}{c}\downarrow \text { microtubule } \\
\text { polymerization; } \\
\downarrow \text { topoisomerase II } \\
\text { (etoposide } \\
\text { and teniposide) }\end{array}$ & $\begin{array}{c}\text { Etoposide and teniposide: } \\
\text { germ-cell malignancies, lung } \\
\text { cancer, Kaposi's sarcoma, soft } \\
\text { tissue sarcomas, leukemias, } \\
\text { non-Hodgkin's lymphoma, } \\
\text { neuroblastoma }\end{array}$ & $\begin{array}{l}\text { Podophyllum peltatum L., } \\
\text { Podophyllum emodi }\end{array}$ & {$[50,56-61]$} \\
\hline & $\begin{array}{c}\uparrow \text { microtubule } \\
\text { polymerization }\end{array}$ & $\begin{array}{c}\text { Kaposi's sarcoma, } \\
\text { breast, head, neck, lung, ovarian } \\
\text { esophageal, prostate and bladder } \\
\text { cancer }\end{array}$ & $\begin{array}{l}\text { Pacific yew trees } \\
\text { (Taxus brevifolia) }\end{array}$ & [62-75] \\
\hline Paclitaxel (above), docetaxel & & & & \\
\hline
\end{tabular}

\section{I and II Topoisomerases Inhibitors}

Topoisomerases are enzymes found in the nucleus responsible for reducing torsion in supercoiled DNA. This activity is essential for intracellular processes such as replication, recombination, repair and transcription [76]. Their mechanism of action is based on the repetitive disruption 
and following ligation of DNA strands [77]. There are two main classes of topoisomerases: type I and type II, both potential molecular targets for anticancer therapeutics. Topoisomerase I relaxes the tension and torsion of the dsDNA using the "controlled rotation" mechanism rather than strand passage by inducing single strand, reversible breaks. Type II topoisomerase family, on the other hand, untangles and relaxes the DNA molecule by passing one strand through the opening they have cleaved beforehand and then resealing the break [76].

Camptothecin is quinoline alkaloid derived from Camptotheca acuminata known for its inhibitory effect on topoisomerase I [78]. Due to severe side effects, preliminary testing of camptothecin-based therapies were eventually abandoned until the the late eighties [78], having been replaced by administering of semisynthetic derivatives like topotecan [79]. This progress allowed the extension of treatment regimens to other agents effective against colorectal cancer [80], small cell lung cancer [81] and leukemia (Table 2).

Among topoisomerase II inhibitors, etoposide (podophyllotoxin ligand derivative), present in Podophyllum peltatum, is worth particular attention due to its widely described antineoplasic properties (Table 2). Dimeric tetrahydroxanthones, isolated from fungus Aspergillus versicolor, are worth mentioning as a new class of potent topoisomerase I inhibitors. They inhibit topoisomerase I-mediated DNA relaxation, induce cell cycle arrest and necrosis of cancer cells [82].

Table 2. Topoisomerases inhibitors-a brief summary. Images of the chemical structures obtained from ChemSpider database [52]. $\uparrow:$ upregulation/induction/stimulation, $\downarrow$ : downregulation/inhibition.

\begin{tabular}{|c|c|c|c|c|}
\hline Structure/Name & Mechanism(s) & Experimental Model & Compound Source & Ref. \\
\hline $\begin{array}{l}\text { Camptothecin (above), } \\
\text { topotecan and irinotecan } \\
\text { (semisynthetic derivatives) }\end{array}$ & $\downarrow$ topoisomerase I & $\begin{array}{l}\text { Colorectal cancer, small } \\
\text { cell lung cancer, } \\
\text { leukemia }\end{array}$ & $\begin{array}{c}\text { Tibetan tree } \\
\text { Camptothecaacuminate }\end{array}$ & {$[79-81,83,84]$} \\
\hline & $\downarrow$ Topoisomerase II & $\begin{array}{l}\text { Leukemia, small cell } \\
\text { lung cancer, testicular } \\
\text { tumors, Hodgkin's } \\
\text { lymphoma }\end{array}$ & Podophyllum peltatum & [85-88] \\
\hline Etoposide & & & & \\
\hline
\end{tabular}

\section{Inducers of Xenobiotics Metabolism}

The enzymes in the metabolic pathway of xenobiotics play a significant role in the prevention of carcinogenesis. It allows for the detoxification and elimination of potentially dangerous chemicals from the body. The oncogenic effect of xenobiotics is neutralized by their biotransformation with the participation of oxidoreductases and transferases in a process consisting of two phases: phase I and phase II [2]. Phase II enzymes are responsible for the so-called detoxification phase, during which xenobiotics are transformed into their variant forms, facilitating their excretion from the body [89]. This process involves the coupling of xenobiotics with endogenous metabolites such as glutathione, glycine as well as glucuronic, acetic, glutamic and sulfuric acids. The coupling reactions lead to the increased solubility of xenobiotics in body fluids, allowing them to be excreted via urine [90].

Glutathione S-transferases (GSTs) are among the most crucial enzymes for the second phase of xenobiotics biotransformation. They catalyze the coupling reactions between reduced glutathione and electrophilic intermediate metabolites formed as a result of the phase I reactions [91]. The coupling 
of xenobiotics with glutathione, in most cases, leads to their inactivation and reduces their cytotoxic activity [92]. The chemopreventive properties of GSTs play an important role in the regulation of carcinogenesis. Another very important characteristic of GSTs is their participation in cellular defense against reactive oxygen species (ROS), which damage various macromolecules present in the cell, such as nucleic acids, proteins, lipids, and are responsible for the development of many pathological conditions-including cancers [93].

Another important enzyme involved in the detoxification of xenobiotics is NADPH: quinone oxidase (NQO1). The main function of NQO1 is the reduction of endogenous and exogenous quinones as well as quinone compounds to hydroquinones [94,95]. Many studies have shown that selective induction of phase II enzymes leads to the cell protection against xenobiotics and reactive oxygen species [96-99]. Thus, modulation of the expression of phase II enzymes may be an important element of the chemopreventive strategy (Figure 1, Table 3).

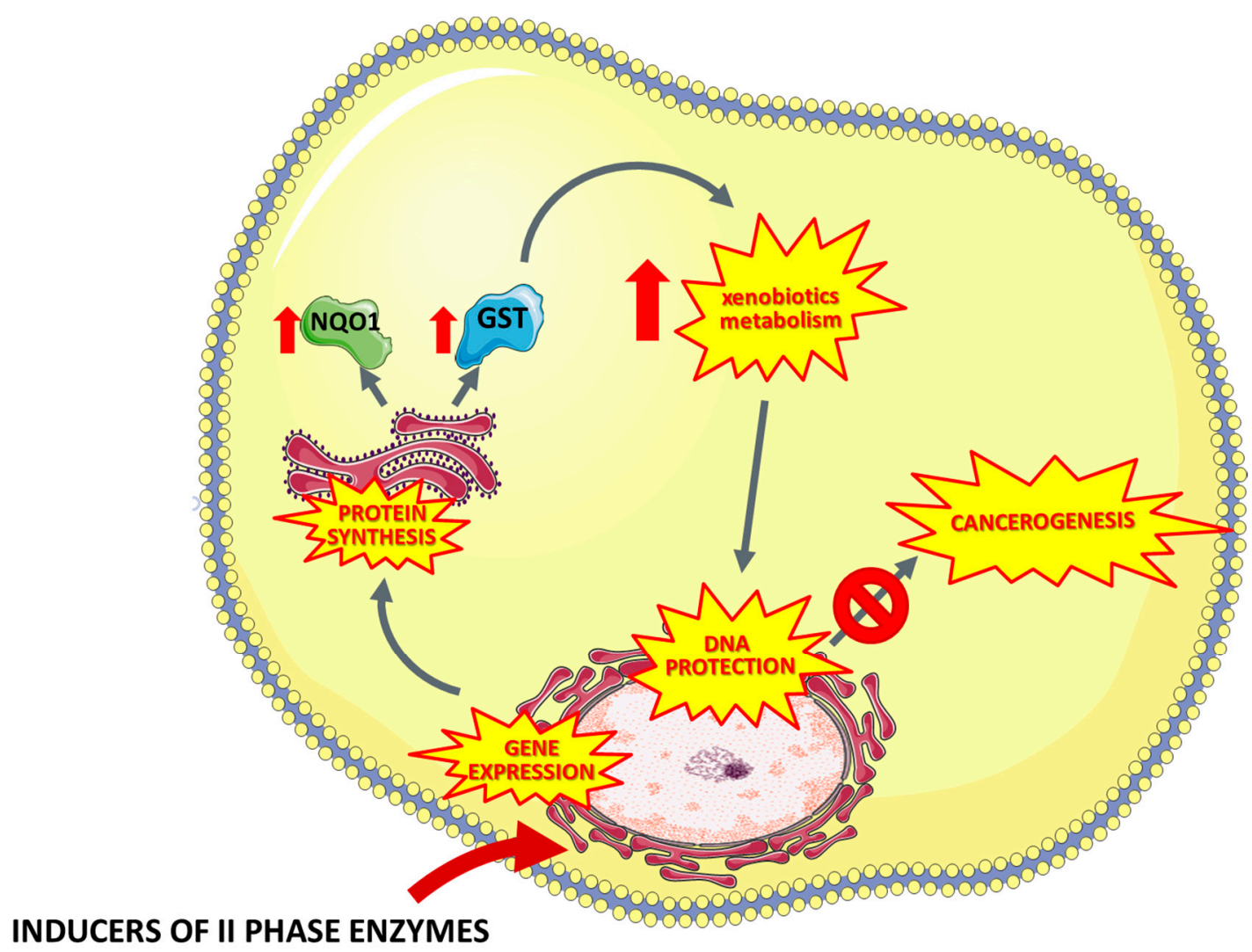

Figure 1. Mechanisms of the chemopreventive activity of the phase II detoxification enzymes (such as organosulfur compounds indole-3-carbinol, isothiocyanates, sulforaphan, glucoraphanin, iberin, phenolic compounds, terpenes, coumarins) leading to inhibition of carcinogenesis. NQO1$\mathrm{NAD}(\mathrm{P}) \mathrm{H}$ dehydrogenase (quinone 1), GST—Glutathione S-transferase. 
Table 3. Inducers of xenobiotics metabolism—a brief summary. Images of the chemical structures obtained from ChemSpider database [52]. $\uparrow$ : upregulation/induction/stimulation, $\downarrow$ : downregulation/inhibition DNMT—DNA methyltransferase, HDACs—histone deacetylase, MMPs—metaloproteinases, miRNAs—microRNA, DADS—diallyl sulfide.

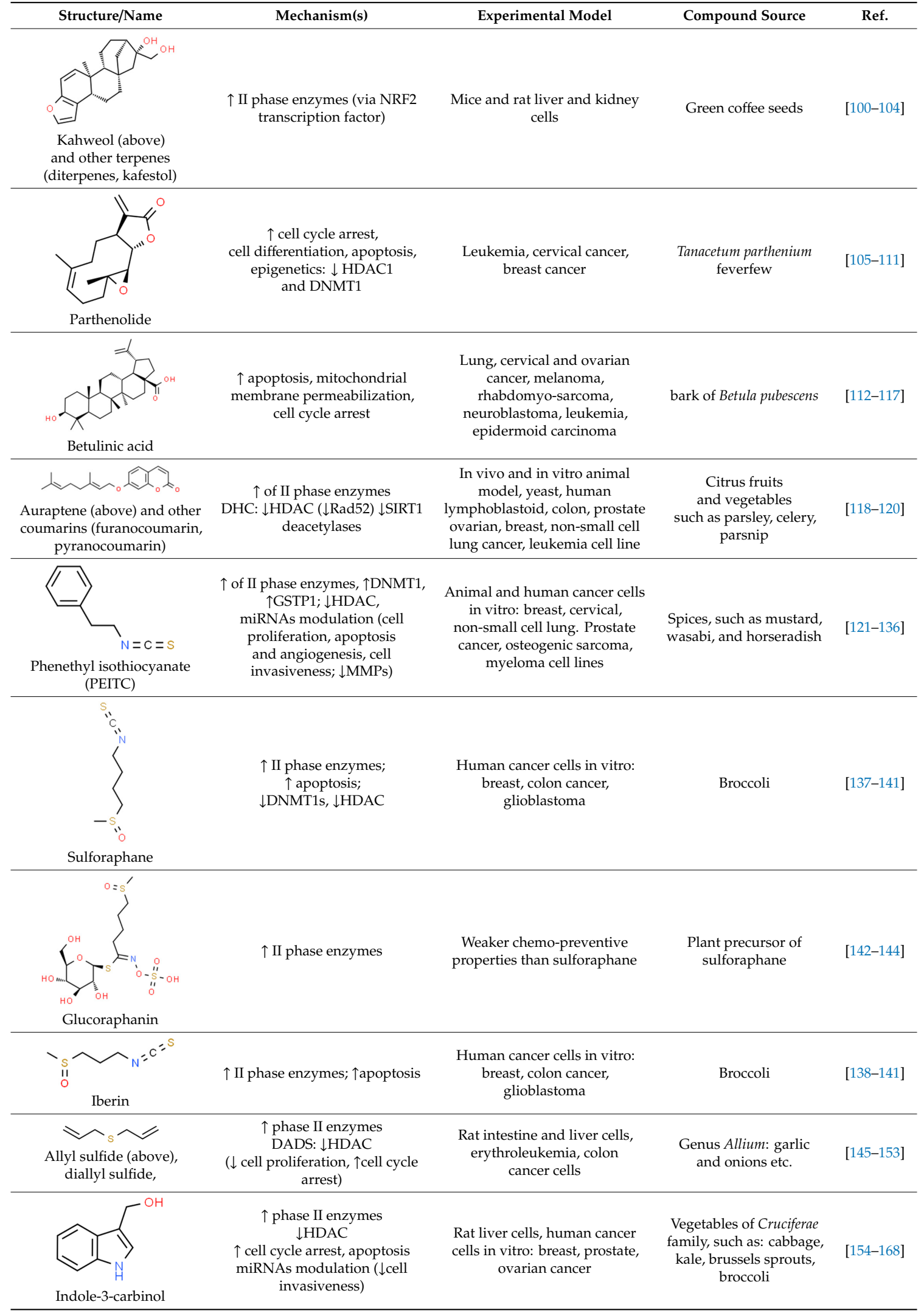




\subsection{Terpenes}

Terpenes (isoprenoids) are a diverse and highly varied family of chemical compounds widely distributed in nature, possessing a broad range of pharmacological and biological properties [100]. They are an example of compounds that induce the synthesis of phase II enzymes by activating the Nrf2 protein (nuclear erythroid 2-related factor) [101]. Nrf2 is a transcription factor that activates many genes encoding proteins such as GST, NQO1 [102]. Studies confirm that diterpenes, kahweol and cafestol, isolated from green coffee seeds, are capable of inducing GST activity in various tissues in mice and increase levels of GST in rat liver and kidneys [103,104].

\subsubsection{Parthenolide}

A sesquiterpene lactone isolated from Tanacetum parthenium — a parthenolide—can be distinguished by its broad anti-cancer properties on the cellular as well as epigenetic level $[11,13]$. Numerous studies reported its involvement in inhibiting NF-kB activation, promotion of cell differentiation, cell cycle arrest or induction of apoptosis [105-108,169]. Apart from these actions, it has been shown to specifically deplete HDAC1 protein (Histone deacetylase 1), causing p53 activation through ubiquitination of E3 ubiquitin-protein ligase MDM2, overall reflecting on DNA damage response $[109,110]$. Parthenolide has been reported to inhibit DNMT1 (DNA (cytosine-5)-methyltransferase 1) activity as well as decrease DNMT1 expression which is linked to the decrease the global DNA methylation, leading to hypomethylation and activation of the HIN-1 tumor suppressor gene in cellular model of leukemia and breast cancer [111].

\subsubsection{Betulinic Acid}

Betulinic acid (BA) is a pentacyclic triterpene derived from the bark of Betula pubescens, Betula pendula, Betula humilis and Betula nana[34x] but also from a variety of tropical plants such as Syzygium formosanum, Tryphyllum peltatum, Diospyros leucomelas, Tetracera boliviana, Ancistrocladus heyneaus and Zizyphus joazeiro [170]. Betulinic acid was proven to induce apoptosis via the mitochondrial pathway by upregulation of the concentration of intracellular ROS level [112]. Interestingly, in cells preincubated with an antioxidative solution, the reaction was not observed [113].

Moreover, betulinic acid has been reported to have no negative effect on normal cells, which is a quality often desirable in anticancer treatment. Its selective cytotoxicity has been tested on different human tumor cell lines in comparison to doxorubicin, a cytostatic agent commonly used in anticancer treatment. Betulinic acid exhibited up to 2-5 times lower cytotoxicity than doxorubicin with doses $\mathrm{IC}_{50} 10 \mu \mathrm{g} / \mathrm{mL}$ and IC $50.38 \mu \mathrm{g} / \mathrm{mL}$, respectively on human normal derma fibroblasts. When tested on peripheral blood lymphocytes (PBL), the difference between betulinic acid and a commonly used anticancer agent was even more significant, showing up to 1000 times less cytotoxicity with tested dosages of doxorubicin and betulinic acid being $\mathrm{IC}_{50} 50 \mu \mathrm{g} / \mathrm{mL}, \mathrm{IC}_{50} 0.058+/-0.008 \mu \mathrm{g} / \mathrm{mL}$, respectively [170].

Betulin itself is inactive when applied to specific cancer cell lines, such as melanoma, neuroblastoma, leukaemia or epidermoid carcinoma. However, it can be easily converted to betulinic acid which exhibits anticancer properties. According to this research, the cytotoxic properties of betulinic acid increase with the decrease in intracellular $\mathrm{pH}$ [114].

The broad spectrum of betulinic acid's mechanisms of action is still being studied, although there is an implication of propensity to interfere with mitochondrial stability by increasing permeabilization of its membrane, which leads to induction of mitochondrial apoptosis pathway [112]. Permeabilization of mitochondrial membrane results in the release of cytochrome $\mathrm{c}$ or apoptosis inducing factor (AIF) to the cytoplasm, where they have ability to activate caspase cascade inevitably triggered to nuclear fragmentation. Antiapoptotic factors, such as $\mathrm{Bcl}-2$ or $\mathrm{Bcl}-\mathrm{X}_{\mathrm{L}}$, suppress apoptosis by stabilizing the mitochondrial membrane, thereby preventing it from permeabilization [115] (Figure 2). Betulinic acid's way of induction of apoptosis is different from those induced by doxorubicin and other anticancer agents, 
since it does not affect ligand/receptor systems such as CD95 or p53 protein [115], but rather interfere with the continuity of mitochondrial membrane which results in the release of cytochrome c [116].

Combination of betulinic acid and other anticancer agents, like vincristine, may give a wide range of different cytotoxic effects [114]. Both are used to induce cell cycle arrest in murine melanoma cell line B16F10, at G1 phase and G2/M phase respectively, therefore one augments the effect of the other [117] which results in induction of programmed cell death. Combination of betulinic acid and tumor necrosis factor (TNF)-related apoptosis-inducing ligand (TRAIL) applied to human neuroblastoma cell line (SHEP), leads to apoptosis of the cells $[114,171]$. Interestingly, in normal cells that effect did not take place. Betulinic acid, doxorubicin, VP16, taxol and actinomycin D induced apoptosis in the SHEP cell line [114]. In some cases, betulinic acid can work as a cell sensitizer for other anticancer agents, such as doxorubicin, in a wide range of cell lines including human melanoma cells MelJuSo, glioblastoma A172 or medulloblastoma Daoy [114].

Recent emergence of a new drug delivery system using gold-based nanomaterials gives a new hope for precise drug dosage due to its low toxicity and photothermal responsive properties, different from properties of the previous gold nanoparticle systems. Different shapes of gold particles have been tested in terms of the photothermal response. Gold nanoshells have been shown to present the most optimal properties for therapy [172]. The new drug delivery system consists of liposomes containing betulinic acid coated with gold particles. BA (betulinic acid) is known from its highly lipophilic properties, which results in its limited bioavailability [173]. The new method of encapsulation of the acid inside liposomes seems to increase the solubility of the particle.

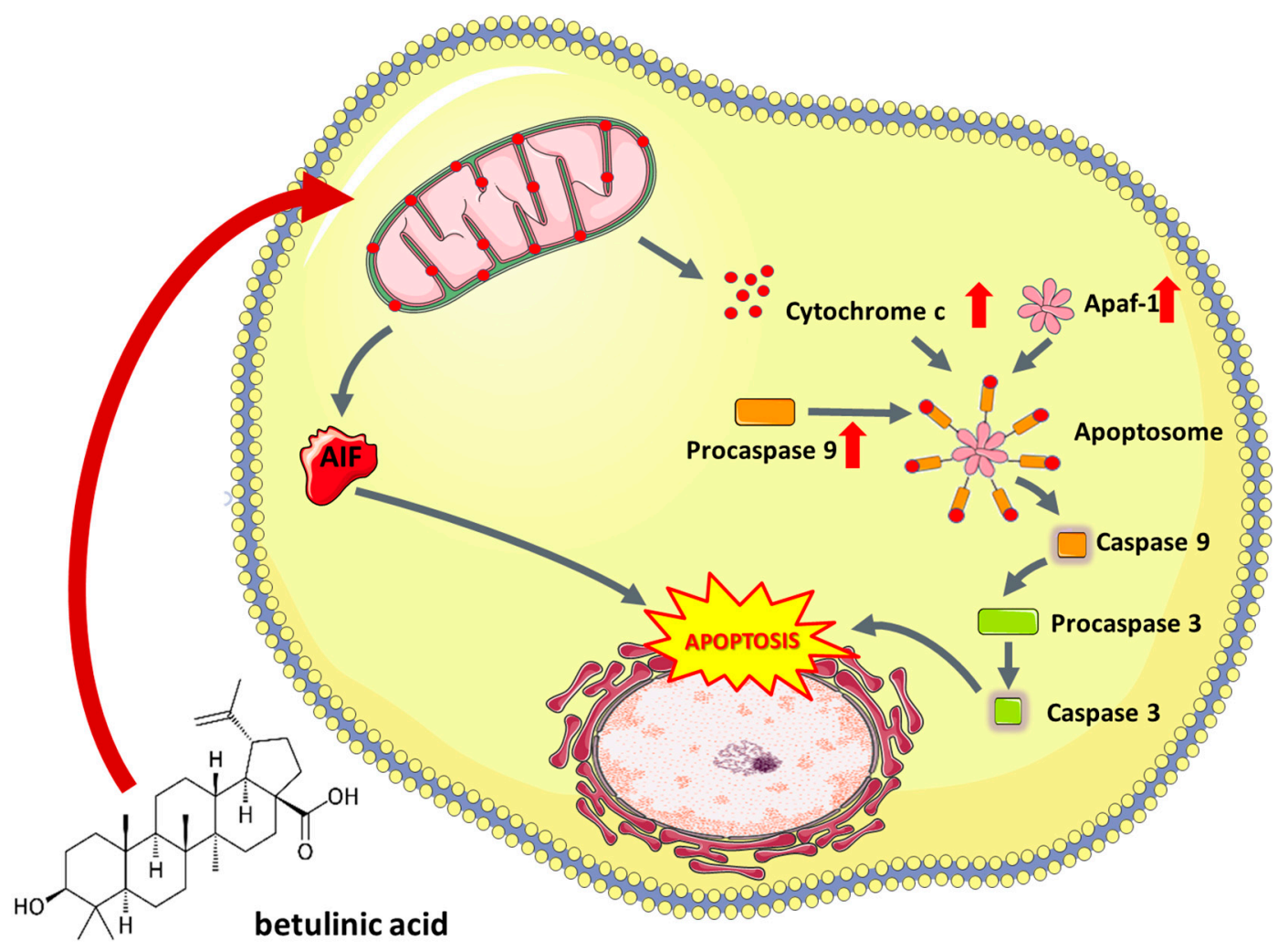

Figure 2. Proapoptotic activity of betulinic acid observed in cancer cells. AIF-Apoptosis Inducing Factor, Apaf-1-Apoptotic protease activating factor 1.

Another way of BA delivery to the tumor tissue may be carbon nanotubes, already widely used in medicine for direct drug delivery. Binding of the BA to nanotubes, called MWCNT-BA, can increase its absorption into the target tissue [174]. The -OH group of BA forms a non-covalent bond with 
the $-\mathrm{COOH}$ group on the external surface of a nanotube. Due to the non-covalent nature of the bond between BA and a nanotube, the release of BA through desorption is facilitated.

\subsection{Coumarins}

Coumarins are glycosides widely present in plant tissues. They are found in citrus fruits and some vegetables such as parsley, celery and parsnips [118]. Van Lieshout et al. (1998) showed that coumarins administered through diet (at a dose of $2500 \mathrm{mg} / \mathrm{kg}$ ) increase the level of glutathione S-transferase in the esophagus, stomach and intestine rat test subjects. [137]. Moreover, auraptene (coumarin present in orange peel), apart from showing protective properties in the tumorigenesis induced by 7,12-dimethylbenzanthracene in the skin of mice [119], significantly increased GST and NQO1 activity in the liver and colon of rats after oral administration [120].

Some initial studies on dihydrocoumarin (DHC) derived from Melilotus officinalis (sweet clover) indicated that coumarins may be involved in epigenetic regulation of proteins involved in carcinogenesis. It has been reported that DHC inhibits SIRT1 deacetylase, leading to concentration- dependent increase in p53 acetylation which contributed to the cytotoxic effect in human lymphoblastoid cell line TK6 [175]. More recent studies conducted on yeast suggested that DHC possesses HDAC inhibitor activity which is associated with inhibition of Rad52, critical to double-strand repair and DNA damage sensitivity [176]. It has been demonstrated that coumarin-based analogues are endowed with HDAC inhibitory and antitumor properties [177]. In addition, recently derived by Abdizadeh et al., coumarin-based benzamides have exhibited significant cytotoxicity and potent HDAC inhibiting activity against six human cancer cell lines (HCT116, A2780, MCF7, PC3, HL60 and A549) [178].

\subsection{Isothiocyanates}

Organic isothiocyanates, commonly found in human diet, are responsible for the spicy, burning taste and aroma of certain foods, such as mustard, wasabi and horseradish [179]. In general, isothiocyanates are breakdown products of glucosinolates induced by plants as a defensive response. The process is often catalyzed by the enzyme myrosinase. Isothiocyanates exhibit strong upregulation of GST and NQO1 in murine models [180].

\subsubsection{Phenethyl Isothiocyanate}

Among isothiocyanates, phenethyl isothiocyanate (PEITC) is of the greatest medical interest. It has been proven to have an anticancerogenic effect in an $\mathrm{N}$-methyl nitrosourea-induced breast cancer animal model [121]. It is worth noting that particularly strong activity of PEITC was observed in melanoma models $[122,123]$. Numerous studies indicate that PEITC has also chemopreventive properties in vitro against: aforementioned breast cancer [124,125], cervical cancer [126], osteogenic sarcoma [127], prostate cancer [128] and myeloma cell lines [129]. Furthermore, PEITC promotes apoptosis by activating caspase-dependent pathways [130]. Therefore, we can conclude that it is not only a chemopreventive substance, but also an active cytotoxic agent that can be utilized against cancer cells.

Wang et al. were among the first to describe the epigenetic modifications caused by PEITC in prostate cancer LNCaP cells, discovering that PEITC reactivates the expression of glutathione S-transferase gene (GSTP1) through demethylation of the GSTP1 gene promoter [131]. The same study demonstrated that PETC influenced histone acetylation and methylation patterns as well as inhibited the activity of HDACs. Recent investigations revealed another epigenetic pathway influenced by PEITC in LNCaP cells, targeting in RASSF1A promoter methylation by DNA methyltransferases (DNMT1, 3A and 3B), resulting in CpG demethylation of those regions, while inhibition of HDAC1, 2, 4 and 6 protein expression was also confirmed [132]. On the other hand, an early study on DS19 mouse erythroleukemia cells treated with allyl isothiocyanate has shown an increase in acetylation of histones without any significant effect on HDACs [133]. In another studies, the modulatory potential of pre-treatment with PEITC on expression of miRNA induced by cigarette smoke was investigated on 
rats in vivo. A broad spectrum miRNAs affected by PEITC was detected, namely: miR-125b miR-26a, miR-146-pre, let-7a, let-7c, miR-192, miR-222-pre, miR-99 and miR- 123 linked to the TGF- $\beta$ expression, NF- $\kappa B$ and Ras activation, as well as cell proliferation, apoptosis and angiogenesis [134]. A similar trial with cigarette smoke was performed on mice to investigate the effect of PEITC along with glucocorticoid budesonide in different combinations. The effect of PEITC on miRNA expression differed among the organs-significant downregulation of nine and upregulation of three miRNAs was observed in the liver while miRNA expression in the lungs was rather moderate. Affected miRNAs were involved in the regulation of stress response, protein repair, cell proliferation, and inflammation [135]. More recent evidence indicates that PEITC may suppress prostate cancer cell invasiveness epigenetically through microRNA-194 mediated downregulation of BMP1, thus resulting in decreased expression of MMP2 and MMP9 (key oncogenic matrix metalloproteinases) [136].

Isothiocyanates are used in the production of nanomolecules. Fluorescein isothiocyanate (FITC) has also found application in biomedical imaging techniques [181]. Studies on the use of FITC with other particles for diagnostic and therapeutic purposes in oncology are currently underway [182,183].

\subsubsection{Sulforaphane and Glucoraphanin}

Sulforaphane (SFN), an isothiocyanate isolated from broccoli, is one of the strongest natural inducers of GSTs and NQO1 [138]. It can be found at high concentrations in mature plants, and in broccoli sprouts up to several days after germinating [139]. The chemopreventive properties of sulforaphane have been confirmed on both in vitro and in vivo animal models [140]. The oncoprotective action of sulforaphane is based on the induction of the glutathione S-transferase in liver cells [137,141]. Many in vitro studies confirm the effective, proapoptotic action of sulforaphane.

The plant precursor for sulforaphane is glucoraphanin, which has weaker chemopreventive properties [142]. Sulforaphane is a product of an enzymatic hydrolysis of glucoraphanin performed by myrosinase, an enzyme released during disintegration of a plant tissue. Unfortunately, during cooking it undergoes denaturation, which reduces the efficiency of active sulforaphane formation. However, due to the enzymatic activity of the microflora living in the large intestine, it is possible to convert glucoraphanin into active isothiocyanates in the final section of the human gastrointestinal tract [143]. Nevertheless, Shapiro et al. (2006) showed that sulforaphane formed, with the participation of intestinal bacteria, is characterized by a six-fold decrease in bioavailability than the compound produced with the participation of the enzyme myrosinase [144]. Therefore, it is beneficial to consume broccoli in a raw or steamed form.

Comprehensive analysis of the transcriptome of Caco-2 cell line treated with SFN has revealed its complex effect on numerous genes linked to carcinogenesis, inter alia transcription factor $2(C D X-2)$, $K L F 4, K L F 5$, cyclin-dependent kinase inhibitor $1 \mathrm{~A}(p 21)$, and $A M A C R$, as well as downregulation of the DNMT1 gene [184]. Another in vitro study on breast cancer cells has addressed epigenetically regulated inhibition of hTERT (human telomerase reverse transcriptase) and downregulation of DNMTs (1 and 3a) along with numerous modifications in acetylation and methylation of histone chromatin in hTERT promoter region [185]. It has been reported that due to its inhibitory effect on HDAC, SFN treatment increases the intracellular level of acetylated histones bound to p21/waf1 promoter. Interestingly, compared to SFN, HDAC inhibition was observed to be more effective in SFN metabolites, SFN-cysteine and SFN-N-acetylcysteine [186]. In other studies HDAC inhibition was linked to induction of p21 and Bax expression leading to cell cycle arrest and apoptosis [187]. Notably, a study on breast cancer confirming the inhibition of HDAC activity by SFN was conducted, but no changes in $\mathrm{H} 3$ or $\mathrm{H} 4$ acetylation were observed after exposure to the compound [188]. In a genome-wide in vitro study on prostate epithelial normal and cancer cells, Wong et al. has proven that SFN affects methylation patterns among promoter regions of cancer-associated genes [189]. In a seminal in vivo study on mice, the inhibitory role of SFN treatment on tumor transformation was addressed with a special emphasis on epigenetic mechanisms associated with anticancer genes such as Nrf2. A stimulating effect was reflected in enhanced nuclear translocation of Nrf2 as well as increased mRNA and protein 
levels of the Nrf2 target genes (HO-1, NQO1, UGT1A1). Epigenetic background of these changes was confirmed by a decrease in the methylation ratio of the Nrf2 gene promoter compared to control, along with decreased histone deacetylase (HDAC) activity and expression of HDACS $(1,2,3,4)$ as well as reduced expression of DNMTs (1,3a and 3b) [190]. Recent in vivo studies have provided another strong indication suggesting the involvement of SFN [191] and its metabolites [192] in epigenetic pathways such as inducing acetylation of histones and inhibiting HDAC activity. Recently, SFN was found to be able to restore the miR-9-3 level in A549 cells in vitro through epigenetic regulation of CpG methylation, hence providing another basis for previously described mechanisms involving DNMT and HDAC activity [193]. Interestingly, an experiment on a murine model [194] as well as in a human trial, reported a decreased HDAC activity in PBMCs after consumption of broccoli sprouts [195].

\subsubsection{Iberin}

Iberin is a natural isothiocyanate found in horseradish [196]. A study conducted by Jakubikova et al. (2006) established that it is a potent inducer of GSTs and NQO1 in vitro. In addition, the antineoplastic effect of iberin is intensified by its action on post-translational histone modification and the induction of apoptotic cell defects [197]. Furthermore, in vivo studies showed that iberin administration to rats resulted in increased expression of detoxifying phase II enzymes (GST and NQO1) [198].

\subsection{Organosulfur Compounds}

Organic sulfur compounds and plant phenolic compounds are usually found in everyday diet [145]. Activity of enzymes in the second phase of biotransformation of xenobiotics is increased by the action of sulfur compounds present in vegetables of the genus Allium, e.g., garlic and onion [146]. Of the natural ingredients in Allium vegetable extracts, allyl sulfide, diallyl disulphide and diallyl trisulphide were proven to significantly increase GST and NQO1 activity in rat liver and colon cancer [147,148].

A growing body of literature has shown that increased histone $(\mathrm{H} 3 / \mathrm{H} 4)$ acetylation can be triggered by OSCs through targeting HDACs [149-153]. An in vitro study on colon cancer has presented DADS as a factor inhibiting cell proliferation and causing cell cycle arrest by triggering a decrease in HDAC activity linked to the histone hyperacetylation accompanied by p21 (Waf1/cip1) expression [153]. DADS metabolite, allyl mercaptan (AM), was shown to be a main contributor to the increase in acetylation of histones in cellular chromatin, reflecting in an accelerated binding of a SP3 transcription factor, followed by recruitment of p53 at the p21/waf1 promoter [151]. Furthermore, compared to several other OSCs, AM has demonstrated the strongest inhibitory potential on HDAC, which was confirmed in subsequent in silico studies.

\subsection{Indole-3-Carbinol}

Indole-3-carbinol (I3C) is present in a form of glucosinolate in vegetables from the Cruciferae family, such as cabbage, kale, brussels sprouts, broccoli [199]. Diindolylmethane (DIM) is a derivative of I3C, formed as a result of its condensation in the acidic environment of the stomach [154]. Both compounds are currently under examination due to their chemo- and oncopreventive properties. Administration of I3C upregulates the activity of NQO1 and GST in rat liver [155]. Both DIM and I3C induce the activity of the second phase enzymes (GST, UGP), showing a synergistic effect with isothiocyanates [156]. It has been proven that DIM and I3C show higher activity in chemoprevention in hormone-dependent tumors such as breast, prostate or ovarian cancer [157]. A vast number of studies have been carried out that confirm the antineoplastic properties of both I3C and DIM. In addition to chemopreventive properties, I3C inhibits the hormonal response in prostate cancer (androgenic response) and in cervical and breast cancer (estrogenic response) [158-160,200].

Some experiments performed on in vitro and in vivo cancer models have reported that DIM is involved in selective proteasomal degradation of class I HDACs (HDAC-1, -2, -3 and -8), while II class HDACs remained unaffected [161]. That phenomenon was associated with abolition of transcription repression of Cdks inhibitors p21/waf1 and p27/Kip2, resulting in cell cycle arrest and DNA damage 
triggered apoptosis. Beaver et al. evaluated the effect of I3C and DIM on prostate cancer in vitro (LNCaP, PC-3 cells, differing in the androgen receptor expression profile), observing the inhibitory effect of DIM on HDAC in both cell lines [162]. On the other hand, I3C has a moderate effect on LNCaP cells, while the PC-3 cells are indifferent to the compound. Another study has investigated the differences in miRNA expression profile in gemcitabine-sensitive and gemcitabine-resistant pancreatic cancer cells treated with DIM, confirming the upregulation of the members of miR-200 and let-7 families, which reflects on downregulation of numerous cancer-related genes [163]. Several other studies have confirmed the effect of DIM on miRNA-mediated downregulation of several cancer-related cell pathways [164,165] including genes linked to the cell invasion: EGFR, MTA-2, IRAK-1, and NF-KB [164]. I3C has been proven to downregulate miR-21 along with affecting PTEN/AKT signaling pathway in vivo [166].

\section{Polyphenols}

Polyphenols are organic compounds containing at least one aromatic ring with one or more hydroxyl functional groups attached. Polyphenols are divided into six groups: flavonols, flavones, isoflavones, flavanones, anthocyanidins, and flavanols (catechins and proanthocyanidins). They belong to a large group of plant secondary metabolites ranging from small molecules to highly polymerized compounds. These substances display many anticarcinogenic properties including inhibitory effects on proliferation of cancer cells, tumor growth, angiogenesis, metastasis, inflammation and induction of apoptosis. Moreover, numerous studies have demonstrated that natural polyphenols could be used for the prevention and treatment of cancer. Additionally, they modulate the immune system response and protect normal cells against damage caused by free radicals. There are many polyphenols which demonstrate anticancer properties, e.g., phenolic acids and their analogues (curcumin, capsaicin, 6-gingerol), tannins (trans-resveratrol), flavonoids (catechins, naringenin, theaflavin), sesamol, coumarin, tannic acid, carnosol etc. In this Section, we focus on the specific properties of 6-gingerol, honokiol and flavonoids to demonstrate the diverse biological activity of polyphenols (Table 4 ).

\subsection{Carnosol}

Carnosol, a natural compound found in rosemary (Rosmarinus officinalis), oregano (Origanum vulgare), and sage (Salvia carnosa) [201,202], has been proven to have antioxidant, anti-inflammatory and anticancer properties in animal models. Due to its strong inhibitory effect on the TPA-induced activation of epidermal ornithine carboxylase activity, carnosol is able to inhibit the development of a variety of papillomas when applied to the skin in murine models [203,204]. Carnosol is capable of halting multiple intracellular pathways, such as the JAK2-STAT3 pathway, which results in inhibition of proliferation of cancer cells by suppression of expression of cyclins and cyclin dependent kinases, and MAPK, Akt pathway, which leads to inhibition of inflammatory response via suppression of NF-k $\beta, C O X-2$ or AP-1 [203]. On the other hand carnosol, is capable of stimulating the activity of the p53 protein which leads to induction of apoptosis via activation of proapoptotic proteins [203]. When it comes to brain tumors, carnosol has been shown to be able to sensitize the glioblastoma multiforme (GBM) cells to chemotherapy by activating the p53 dependent apoptotic pathway [205]. Glioblastoma multiforme is one of the most aggressive and invasive cancers. The main aim of the treatment is to target the CSC cells, a subpopulation of cancer cells having proliferative, multipotent and self-renewal properties. Research has shown that the classic antitumor agent used to treat gliomas has a better effect on cancer cells when coupled with carnosol [206]. Furthermore, carnosol reduces CSC's self-renewal ability.

Carnosol has antiproliferative effects on breast cancer cells expressing the estrogen receptor (ER) [205]. In the JB6 cell line, carnosol was shown to halt the Ras/ERK pathway by inhibition of RSK by directly binding to it. In gastric cell lines, carnosol has been proven to accumulate cells in the G2 
phase of the cell cycle, causing cell cycle arrest. As a result, expression of cyclin B1 and protein p53 was increased [207].

Interestingly, there is a difference in the performance of carnosol as an anticancer agent between intraperitoneal delivery of the compound and dietary delivery. The former showed significant anticancer properties, whilst the latter failed to exhibit such properties [208] which may suggest differences in bioavailability of carnosol after dietary administration. However further investigation of the subject revealed that a two-week dietary administration of rosemary extract can impede the development of a mammary gland tumor in rodent models. Both carnosol and carnosoic acid induced apoptosis in B-lineage leukemia cells in vitro by downregulating the Bcl2 protein, which results in cell cycle arrest in the phase G2/M [209].

The most efficient method of administering carnosol is still to be determined. Among the tested ways of administration, DMSO was proven to be the least cytotoxic solvent for carnosol. When dispersed in liposomes, carnosol had an antiproliferative, but also cytotoxic effect on the peritoneal macrophages, where proliferation was reduced to $60 \%$ compared to control. However, this effect was only noticeable at carnosol concentration of 2,79 mg/mL, while at 0,04 and $0,17 \mathrm{mg} / \mathrm{mL}$ the effect was not observed. Carnosol dissolved in DMSO showed no cytotoxic effect, but also the proliferation of the cells was not affected [210]. The synergistic effect of carnosol and other plant derived compounds has been evaluated and phytochemicals such as capsaicin, quercetin and rosmarinic acid, show a limited anticancer activity on their own, but exhibit a stronger effect when combined with carnosol [209].

\subsection{Resveratrol}

Resveratrol (3,5,4'-trihydroxystilbene) is a phenolic compound existing in cis- and trans-isomeric forms, that is synthesized by plants in an event of fungal attack or injury. It has been used in traditional oriental medicine, extracted from Polygonum cuspidatum root [211]. However, it is also abundant in the skin of Vitis vinifera (common grape). Moreover, it is present in lower quantities in dietary products, such as cranberries, bilberries, blueberries, peanuts and pistachios [212-214]. Resveratrol drew scientists' attention after epidemiological studies revealing cardioprotective properties of red wine [215]. In addition, clinical trials show its neuroprotective and antidiabetic properties, a positive role in non-alcoholic fatty liver diseases treatment, and an ability to act against different cancer types (prostate, breast, colorectal) [216]. A molecular mechanism underlying the anticancer properties of resveratrol is the targeting of COX proteins to downregulate tumor proliferation by inhibition of the inflammation process. Additionally, it downregulates transcription factors such as NF- $\mathrm{KB}$ and AP-1. Resveratrol induces cell cycle arrest and leads to apoptosis via the upregulation of survivin and $\mathrm{Bcl} 2$, while downregulating both $\mathrm{BAX}$ and p53. Resveratrol is also capable of targeting hormone signaling and due to its anti-estrogenic properties, finds a use in the treatment of hormone-dependent cancers. Chemopreventive properties are obtained by downregulation of HIF- $1 \alpha$ as well as MMPs which influences angiogenesis and metastasis of a tumor [217]. However resveratrol might be an overall health booster by activating the MPK/SIRT1/PGC- $1 \alpha$ pathway and, similarly to serum starvation, downstream activating key stress signaling pathways connected to TyrRS-PARP1-NAD1, which promotes metabolic health and longevity $[218,219]$.The long-term knowledge about activation of sirtuin 1-a deacetylase-makes resveratrol one of the earliest nutraceuticals associated with epigenetic activity. It was described in literature as de-repression factor of tumor suppressors such as BRCA-1, NRF2 and RASSF- $1 \alpha$ by methylation, PAX1 by acetylation and PTEN by both methylation and acetylation, in addition to the epigenetic regulation of oncogenic NF- $\mathrm{kB}$ and STAT3 signaling [220]. Furthermore, resveratrol has a positive influence on alteration of the miRNA expression ratio-high level of oncogenic miRNAs and low expression of tumor-suppressive miRNAs are commonly observed in cancer cells, thus significantly contributing to inhibition of tumor development and progression [221,222]. Resveratrol has also been demonstrated as weak DNMTs inhibitor [223]. Vergara et al. performed a proteome analysis on OVCAR-3 ovarian cancer cells treated with the compound, proving its ability to downregulate post-transcriptional cyclin D level. After showing 
its influence on Akt/GSK and ERK signaling pathways responsible for cyclin D1 phosphorylation and degradation, they suggested the poliphenol's future clinical use in association with other drugs targeting Akt/GSK and ERK [209]. Although absorption of resveratrol administered orally reaches up to $75 \%$, the bioavailability is lesser than $1 \%$ because of intensive metabolism in the intestine and liver. To avoid this disadvantageous process, a vast number of nanoformulations were produced and tested. They include liposomes, polymeric nanoparticles, solid lipid nanoparticles and cyclodextrins. None of the carriers are perfect so far. For instance, the main drawback of liposomes and solid lipid nanoparticles is low loading capacity, whereas cyclodextrins exhibit poor cancer targeting. Nevertheless, continued research in nanomaterial synthesis field may provide an attractive delivery system [224].

\subsection{6-Gingerol}

Ginger (Zingiber officinale Roscoe) is a tropical plant originally found in Southeast Asia [225]. The aromatic rhizomes of ginger, both fresh and processed, are commonly used not only as a spice or a dietary supplement, but also in medicine [226]. In particular, ginger has been used in traditional oriental medicine to cure various symptoms such as rheumatic disorders and muscle pain [227]. Many beneficial properties were attributed to this plant including anti-inflammatory, antioxidative, anticancer, antimicrobial, antifungal and antiviral activity [228].

6-Gingerol (5-hydroxy-1-(4'-hydroxy3'-methoxyphenyl)-3-decanone) is one of the most abundant constituents of fresh ginger and is responsible for most therapeutic properties of this plant [229]. Numerous studies have shown that 6-gingerol effectively inhibits COX-2 induction [230], hyperproliferation and inflammatory processes [231]. Moreover, this compound inhibits angiogenesis [232] and metastasis [233]. Due to antitumor and proapoptotic potential, 6-gingerol has been tested in vitro in a wide variety of cell lines, e.g., leukemia [234], breast [235], endometrial prostate [236], liver [237], colon [238], glioblastoma [239] and pancreatic cancer cell lines [240]. 6-Gingerol affects numerous pathways associated with cell death, oxidative stress, cell division and growth processes. It was reported that 6-gingerol works through the inhibition of inducible nitric oxide synthase (iNOS) [234], suppression of I- $\mathrm{kB} \alpha$ [241], nuclear activation of NFkB, translocation of protein kinase C (PKC- $\alpha$ ) [242], caspase activation [243], release of cytochrome c, increase in the expression of apoptotic protease-activating factor-1 (Apaf-1) [244], induction of oxidative stress, DNA damage [234], autophagy induction and activation of tumor suppressor proteins including p53 and p21, which leads to apoptosis (Figure 3). The ability of 6-gingerol to suppress angiogenesis is associated with inhibiting both the VEGF- and bFGF-induced proliferation of human endothelial cells and cell cycle arrest in the G1 phase [232]. Research conducted by Bode et al. showed that 6-gingerol could also block EGF-induced cell transformation and inhibit of AP-1 activation [245].

The data describing the activity of 6-gingerol as a epigenetic modulator is scarce, however Rastogi et al. suggested that apoptosis of myeloid leukemia cells treated with 6-gingerol was associated with miRNA-mediated inhibition of the PPAR $\gamma-\mathrm{NF}-\mathrm{kB}$ pathway through miR-27b [234].

The role of ginger in cancer prevention has been investigated in several randomized controlled trials. One of these studies involved patients at increased risk for colorectal cancer (CRC) [246]. The results suggest that daily consumption of ginger reduces proliferation in the crypts of normally appearing colorectal epithelium and promotes apoptosis. There are also numerous in vivo animal studies which have shown that ginger consumption is associated with a reduced risk of cholangiocarcinoma [247], liver [248], pancreatic [249] and gastric [250] cancer. Due to the poor water solubility of 6-gingerol, scientists have investigated the combination of 6-gingerol with nanoparticles which provided a prolonged drug effect [251] and, moreover, caused a significant regression of colon cancer when ginger was administered with calcium alginate [252]. Therefore, the use of 6-gingerol in chemoprevention holds a promising future with highly beneficial potential for the control and treatment of cancer [241]. 


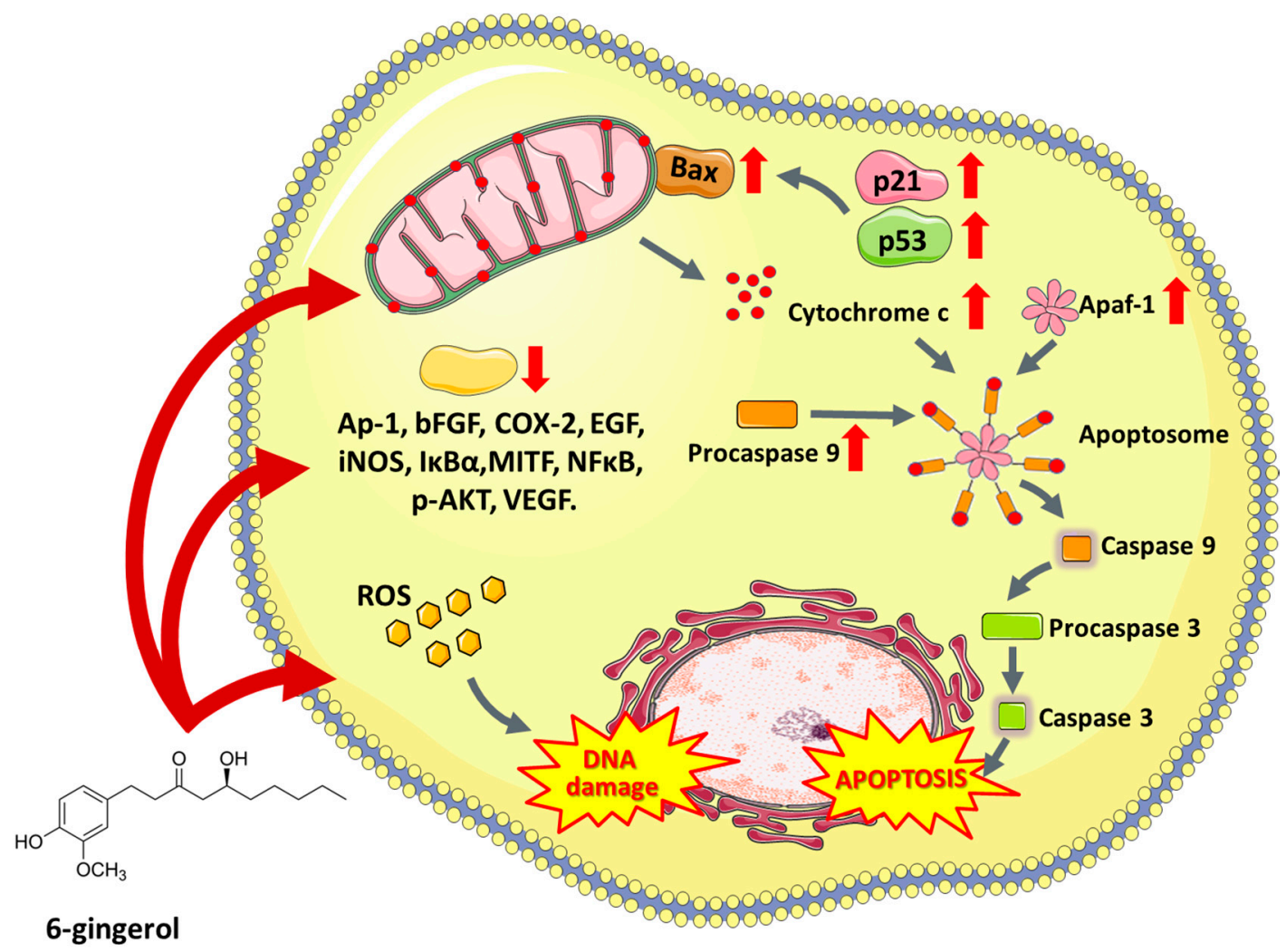

Figure 3. The multi-level effect of 6-gingerol (5-hydroxy-1-(4'-hydroxy3'-methoxyphenyl)-3-decanone) on cancer cells. Apaf-1-Apoptotic protease activating factor, Ap-1-Activator protein 1, Apaf-1-Apoptotic protease activating factor 1, Bax-BCL2 associated X protein, bFGF-basic fibroblast growth factor, COX-2 - Prostaglandin-endoperoxide synthase 2, EGF-Epidermal growth factor, iNOS-Nitric oxide synthases, I $\mathrm{KB} \alpha-$ Nuclear factor of kappa light polypeptide gene enhancer in B-cells inhibitor, alpha, MITF-Microphthalmia-associated transcription factor, NFKB - Nuclear factor kappa-light-chain-enhancer of activated B cells, p-AKT_-Protein kinase B (phosphorylated), VEGF-Vascular endothelial growth factor.

\subsection{Honokiol}

Magnolia-derived agents have been strongly appreciated, even a hundred years ago, and medicaments being produced from cortex, cones and leaves of this plant were commonly used in ancient western medicine. One of the most common polyphenolic and low-toxic anticancer compounds isolated from Magnolia officinalis is honokiol (3',5-di-(2-propenyl)-1,1'-biphenyl-2,4'-diol) [253].

According to recent in vitro studies, honokiol shows anticancer activity against miscellaneous cancer cell lines, e.g., Hep-G2 cells (hepatocellular carcinoma) [254], melanoma cell lines SK-MEL-2 [255], MeWo [256], pancreatic cancer [257] and human epidermoid A431 squamous skin cancer [258]. Honokiol inhibits NF- $\mathrm{KB}$ activation through the suppression of Akt and activation of IKK (inhibitor kinase) [253]. Furthermore, this agent plays a major role in inhibition of EGFR signaling in head and neck squamous cell carcinoma cells [259] and inhibition of mammalian target of rapamycin (mTOR) kinase responsible for controlling cell metabolism, growth and proliferation [253]. Moreover, due to the ability to decrease P-glycoprotein expression, honokiol is an object of interest for scientists involved in oncology as some studies have revealed that pretreatment with honokiol overcomes the resistance to cytostatics [260]. Wang X. et al. (2011) showed that honokiol may cross the blood-brain barrier and inhibit growth of human U251 xenograft glioma model [261]. Furthermore, this substance exhibits neuroprotective properties through a wide range of mechanisms and, therefore, is likely to become an interesting alternative for standard treatment for patients diagnosed with brain tumors. However, despite the aforementioned excellent properties, honokiol is not a perfect agent. It also has its disadvantages, 
namely poor bioavailability [262]. One of the last successful strategies to overcome this phenomenon was the use of nanomicellar particles which increase its bioavailability and anticancer effects [263].

\subsection{Flavonoids}

Flavonoids are a very diverse group of compounds displaying anti-proliferative effects in many cancer cell lines [264-266]. Thanks to their ability to neutralize the effects of oxidative stress as well as inhibit kinase activity and glucose uptake [267], flavonoids have caught the attention of researchers in recent years. Some flavonoids are capable of binding to cellular receptors, and thus alter cell proliferation [268]. Additionally, flavonoids are widely known as compounds altering multidrug resistance (MDR) phenomenon in cancer cells. For example, naringenin enhances the anti-tumor effect of doxorubicin by selectively modulating drug efflux pathways and increases the level of doxorubicin concentration in the cells overexpressing MDR associated proteins, and may find its application as an adjuvant drug in the treatment of human tumors [269]. Due to suboptimal pharmacokinetics and low bioavailability in the cancer sites, the application of naringenin in cancer is limited, which creates the necessity of using alternative drug delivery systems. The nanoparticle system of naringenin (NARNPs) was tested on human cervical carcinoma (HeLa) cells. The results showed that using NARNPs produces dose-dependent cytotoxicity as well as apoptosis. Moreover, NAPNPs caused alterations in mitochondrial membrane potential, increased intracellular ROS level and reduced intracellular GSH (glutathione) level [270].

\subsubsection{Green Tea Flavonoids}

Green tea contains many flavonoids such as epigallocatechin gallate (EGCG), epicatechin gallate, epigallocatechin, epicatechin and catechin [271]. They are among the strongest antioxidants and it has been proven that long-term consumption of green tea extracts increases the activity of glutathione S-transferase (GST) [272]. Drinking green tea increases the expression of oxidative stress enzymes, (e.g., superoxide dismutase) and inhibits the activity of lipo- and cyclooxygenase, xanthine oxidase, activator protein 1 and NF-KB transcription factors [273]. It is believed that the antitumor effect of green tea polyphenols is based on the induction of apoptosis [274], inactivation of transcription factors [275], cell cycle arrest in G1 phase [276] as well as inhibition of DNA synthesis and [277] activity of topoisomerase I [278] (Figure 4). Green tea compounds also affect formation of new capillaries, which limits the risk of tumor metastasis by reducing the supply of glucose and oxygen to cancer cells [279]. According to recent studies, polyphenols present in green tea affect multi-drug resistance by altering the expression of membrane proteins from the ABC family [274], breast cancer resistance protein (BCRP) [280,281], lung resistance protein (LRP) [281,282], ATP-dependent glutathione S-conjugate export pump [281,283], copper transporter CTR1 [284] or p-glycoprotein [281].

Numerous studies have identified EGCG to be epigenetically involved in modulation of carcinogenesis through DNA methylation (e.g., hypermethylation CpG islands) as well as histone modifications [285-292]. It is well known that EGCG possesses an inhibitory activity on DNMT [285,286,293], and HDAC [286-288,292] which reflects on reactivation of epigenetically silenced genes (p16 (INK4a), retinoic acid receptor beta $(\mathrm{RAR} \beta), \mathrm{O}(6)$-methylguanine methyltransferase (MGMT), human mutL homologue 1 (hMLH1) TIMP-3 [292] and acetylation glutathione-S transferase pi (GSTP1) [286,287]. An illustrative paper by Thakur et al. described proteasomal degradation of class I HDACs in human prostate cancer cells caused by green tea polyphenols treatment [287]. Notably, altered methylation patterns in promoter regions of tumor-suppressing genes caused re-expression of those in HeLa cells exposed to EGCG [294]. Another study demonstrated that EGCG decreased the invasive ability of cystic and adenoid cystic carcinoma SACC83 cells through the up-regulation of RECK protein [295]. Emerging evidence suggests that EGCG modulates polycomb group proteins (PcG) such as Bmi-1 and EZH2 [290,291] which corresponds to a decrease in repressive chromatin marks. A cutting-edge study by Chen et al. [296] presented comprehensive analysis of genome-wide methylation and mRNA expression in oral squamous carcinoma OSCC treated by EGCG. 
A total of 761 differentially methylated gene loci and 184 downregulated transcripts were reported and associated with the key metabolic pathways, as well as mitogen activated protein kinase (MAPK), Wnt signaling, and regulation of the cell cycle.

Several clinical trials have investigated the role of tea polyphenols in cancer prevention. Some studies suggest a protective role of green tea against lung [297], stomach [298], liver [299], colorectal [300], breast [301], and prostate [302] cancers. Drinking green tea has been shown to have beneficial effects in protecting the human body against oral premalignant lesions [303], oxidative DNA damage among smokers [304] as well as liver [305] and prostate cancers [306]. Today there are also considered alternative methods for enhancing anti-tumor activities of green tea polyphenols, such as the use of special nanoparticles [307-310] and electrochemotherapy [311,312].

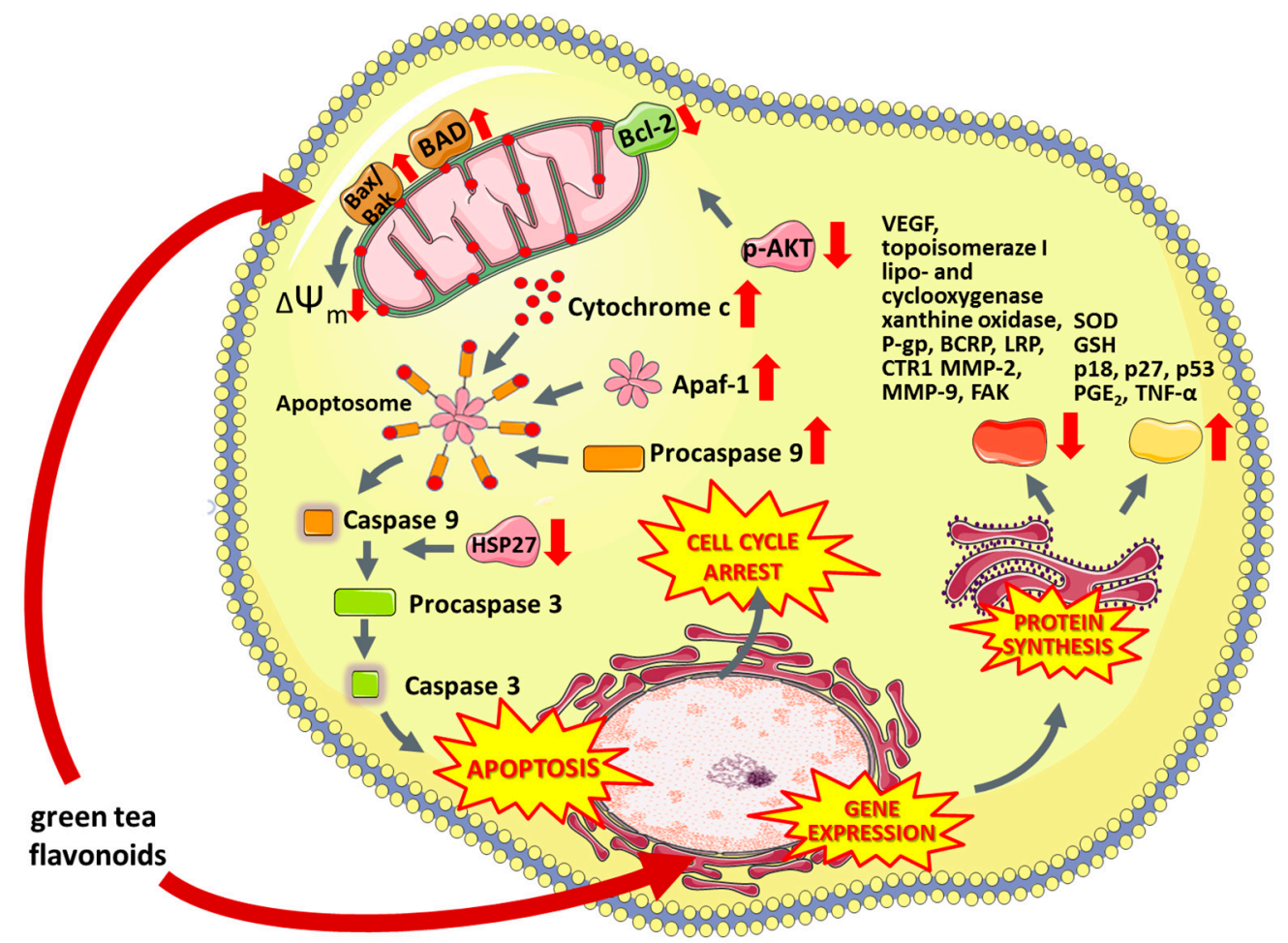

Figure 4. The multi-level anti-cancer activity of green tea flavonoids. $\Delta \Psi \mathrm{m}-$ Mitochondrial membrane potential, Apaf-1-Apoptotic protease activating factor, BAD-Bcl-2-associated death promoter, Bak-Bcl-2-antagonist killer, Bax-bcl-2-like protein 4, Bcl-2-B-cell lymphoma 2, BCRP-ATP-binding cassette super-family G member 2, CTR1-High affinity copper uptake protein 1, FAK—focal adhesion kinase, GSH—Glutathione, HSP-29—-heat shock protein 29, LRP-Low density lipoprotein receptor-related protein, MMP-2-Matrix Metalloproteinase 2 Protein, MMP-9-Matrix Metalloproteinase 2 Protein, p18-Cyclin-dependent kinase 4 inhibitor C, p27-Cyclin-dependent kinase inhibitor 1B, p53-tumor protein p53, p-AKT-Protein kinase B (phosphorylated), PGE2-Prostaglandin E2, P-gp-P-glycoprotein 1, SOD-Superoxide dismutase, TNF- $\alpha$-tumor necrosis factor alpha, VEGF-Vascular endothelial growth factor.

\subsubsection{Caffeic Acid Phenethyl Ester and Caffeic Acid}

Propolis is a compound of natural origin produced by bees-a mixture of bees' saliva, beeswax and plant secretions [313]. Propolis consists of over 300 substances, most significant of which are flavonoids and phenolic acid. Among many active compounds found in propolis, caffeic acid phenethyl ester (CAPE) appears to be the most remarkable. Numerous studies have been performed to confirm its cytotoxic properties against tumor cells [314] as well as its antioxidant, anti-inflammatory, anticarcinogenic, antiviral, immunomodulatory, antihepatotoxic, neuroprotective, antiatherosclerotic activity [315-322]. The molecular targets of CAPE are proteins such as: ROS, COX-1, COX-2, NF- $\kappa \beta$, 
NFAT, AP-1, CYP2El, HIV1-integrase [315,321,323,324]. CAPE is also an apoptosis-inducing factor (Figure 5) which induces the apoptotic pathway via targeting p53, p38 and caspase-3 activity, inhibition of Bax and Bak and stimulation of Fas receptors [322,325-327]. Studies have reported CAPE to be a NF- $\kappa \beta$ inhibitor; however, the induction of apoptosis by CAPE in PC-3 cells seemed to be entirely caspase-dependent [328]. In addition, CAPE may deplete intracellular supplies of GSH and trigger the ROS induced apoptotic pathway [329]. CAPE is also a selective inhibitor of both glutathione S-transferase [330] and matrix metalloproteinases (MMPs) [329,331]. In the HT1080 human fibrosarcoma cell line treated with CAPE, the compound exhibited a dose-dependent decrease in MMP activity [329]. What is more, CAPE has been proven to be able to affect oxidative stress pathways connected to p53-independent pathways to inhibit the growth of tumor cells.

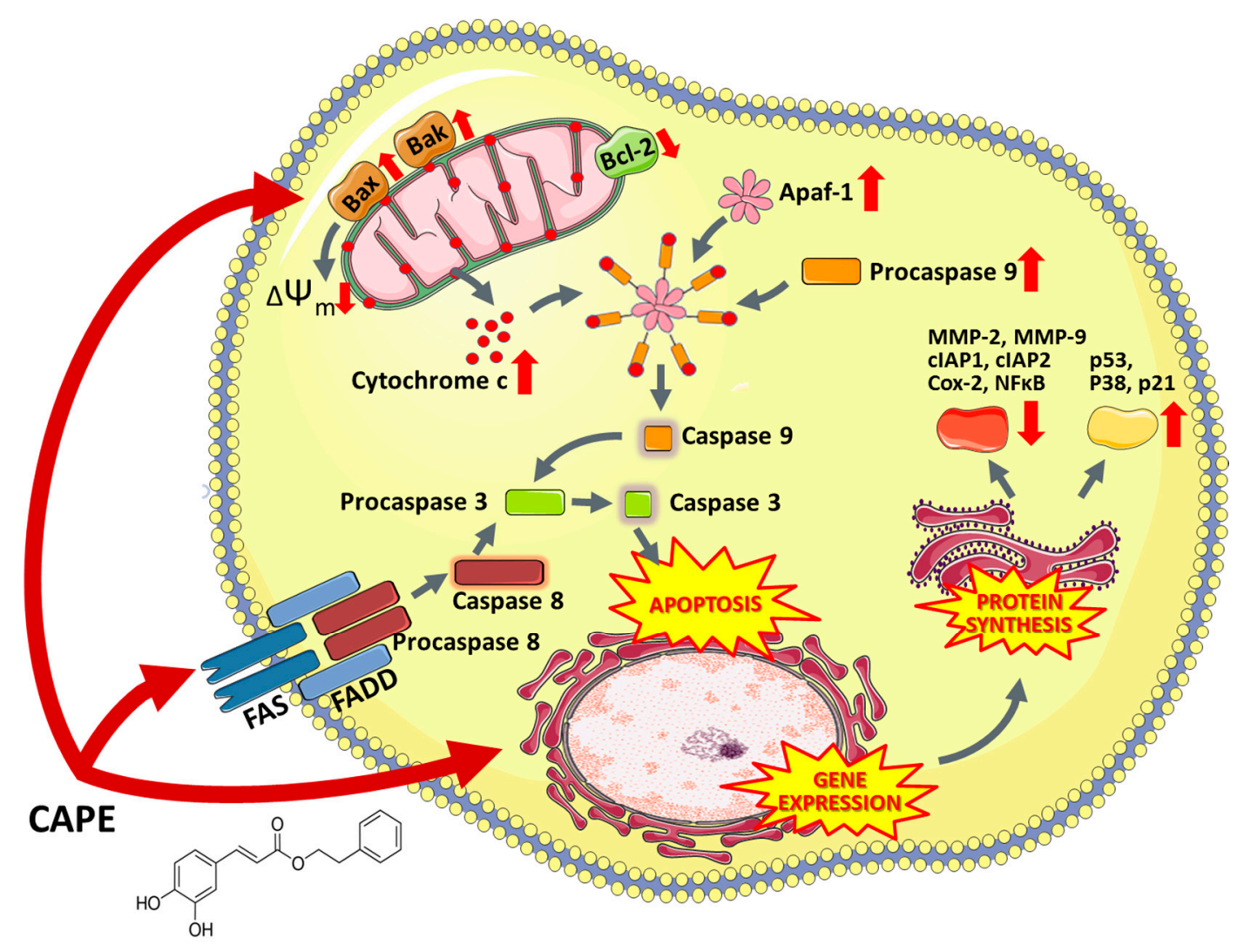

Figure 5. Mechanism of action of CAPE (Caffeic acid phenethyl ester) in cancer cells. $\triangle \Psi \mathrm{m}-$ Mitochondrial membrane potential, Apaf-1-Apoptotic protease activating factor, Bak-Bcl-2-antagonist killer, Bax-bcl-2-like protein 4, Bcl-2-B-cell lymphoma 2, cIAP1-Cellular inhibitor of apoptosis protein-1, cIAP2 - Cellular inhibitor of apoptosis protein-2, COX-2 - Prostaglandin-endoperoxide synthase 2, CTR1—High affinity copper uptake protein 1, FAK—Focal adhesion kinase, FAS—Apoptosis antigen 1, FADD—Fas-associated protein with death domain, GSH - Glutathione, HSP-29—Heat shock protein 29, LRP—Low density lipoprotein receptor-related protein, MMP-2-Matrix Metalloproteinase 2 Protein, MMP-9—Matrix Metalloproteinase 2 Protein, NFKB - Nuclear factor kappa-light-chain-enhancer of activated B cells, p21-Cyclin-dependent kinase inhibitor 1, p38 - p38 mitogen-activated protein kinases, p53-Tumor protein p53, p-AKT—Protein kinase B (phosphorylated).

Lee et al. (2006) were among the first to demonstrate that caffeic acid is involved in epigenetic mechanisms through the inhibition of DNMT in a non-competitive mechanism, resulting in decreased DNA methylation. Those findings were supported by in vitro experiments on human breast cancer cells (MCF-7 and MAD-MB-231) treated with caffeic acid, showing partial inhibition of the methylation of the promoter region of the RARb gene [332]. Another in vitro study on breast cancer reported the accumulation of acetylated histone proteins after incubation with CAPE, suggesting its HDAC 
inhibitory properties [333]. More recent evidence demonstrated a time-dependent reduction of global DNA methylated status induced by caffeic acid accompanied by a concomitant reduction of DNMT1 expression level [334].

Table 4. Polyphenols—a brief summary. Images of the chemical structures obtained from ChemSpider database [52]. $\uparrow$ : upregulation/induction/stimulation. $\downarrow$ : downregulation/inhibition GBM—Glioblastoma multiforme, MDR—Multi-drug resistance, PcGs—Polycomb group proteins.

\begin{tabular}{|c|c|c|c|c|}
\hline Structure/Name & Mechanism(s) & Experimental Model & Compound Source & Ref. \\
\hline Carnosol & $\begin{array}{c}\downarrow \text { CDKs, JAK2-STAT3, MAPK, } \\
\text { Akt pathways; } \\
\uparrow \text { cycle arrest, p53 pathway }\end{array}$ & $\begin{array}{c}\text { (GBM), breast, colon, skin, } \\
\text { ovarian, prostate cancer, } \\
\text { leukemia } \\
\text { macrophage cell lines, }\end{array}$ & $\begin{array}{c}\text { (Rosmarinus officinalis), } \\
\text { oregano } \\
\text { (Origanum vulgare), } \\
\text { sage (Salvia carnosa }\end{array}$ & [201-208,210] \\
\hline $\begin{array}{l}\mathrm{OH} \\
\text { Resveratrol }\end{array}$ & $\begin{array}{c}\text { Targeting COX }(\downarrow \text { tumor } \\
\text { proliferation }) \\
\uparrow \text { cell cycle arrest } \\
\downarrow \text { NF- } \mathrm{B} \text { AP- } 1, \text { HIF- } 1 \alpha \text {, MMPs } \\
\uparrow \text { BRCA- } 1 \text {, NRF2, RASSF- } 1 \alpha ; \\
\text { miRNAs modulation; } \\
\downarrow \text { HDACs, DNMTs }\end{array}$ & $\begin{array}{c}\text { many cancers in vitro } \\
\text { and in vivo (e.g., prostate, } \\
\text { breast, colorectal cancer) } \\
\text { Clinical trials }\end{array}$ & $\begin{array}{c}\text { Polygonum cuspidatum } \\
\text { root, } \\
\text { Vitis vinifera } \\
\text { (common grape) }\end{array}$ & {$[22,216,217,220]$} \\
\hline 6-gingerol & $\begin{array}{l}\downarrow \text { angiogenesis, metastasis; } \\
\uparrow \text { apoptosis antitumor, } \\
\text { antioxidant activity } \\
\text { miRNAs modulation }\end{array}$ & $\begin{array}{c}\text { Leukemia, breast, prostate, liver, } \\
\text { colon, glioblastoma } \\
\text { and pancreatic cancer }\end{array}$ & $\begin{array}{l}\text { Rhizome of ginger } \\
\text { (Zingiber officinale } \\
\text { Roscoe) }\end{array}$ & [234-240] \\
\hline Honokiol & $\begin{array}{c}\uparrow \text { apoptosis; } \\
\downarrow \text { EGFR signaling, } \\
\text { P-glycoprotein }\end{array}$ & $\begin{array}{l}\text { Hepatocellular carcinoma, } \\
\text { melanoma, pancreas, } \\
\text { epidermoid squamous skin } \\
\text { cancer, glioma, head and neck } \\
\text { squamous cancer }\end{array}$ & $\begin{array}{c}\text { Cortex, cones } \\
\text { and leaves of } \\
\text { Magnolia officinalis }\end{array}$ & {$[254-258,261]$} \\
\hline $\begin{array}{l}\mathrm{OH} \quad \mathrm{O} \\
\text { Naringenin }\end{array}$ & $\begin{array}{l}\downarrow \text { proliferation, } \\
\text { kinase and glucose uptake; } \\
\text { } \text { apoptosis; antioxidant } \\
\text { activities; MDR modulation }\end{array}$ & Breast and colon cancer & $\begin{array}{l}\text { Grapefruit, } \\
\text { orange etc., }\end{array}$ & {$[264-269,335,336]$} \\
\hline $\begin{array}{l}\text { Green tea flavonoids } \\
\text { epigallocatechin gallate } \\
\text { (above), epicatechin gallate, } \\
\text { epigallocatechin, epicatechin } \\
\text { and catechin }\end{array}$ & $\begin{array}{l}\downarrow \text { proliferation, angiogenesis, } \\
\text { DNA synthesis, } \\
\text { } \text { apoptosis, cell cycle arrest; } \\
\downarrow \text { HDACs, ( } \downarrow \text { cell invasiveness) } \\
\text { DNMTs antioxidant activities; } \\
\text { MDR modulation, PcGs } \\
\text { modulation. }\end{array}$ & $\begin{array}{l}\text { Many cancers in vitro } \\
\text { and in vivo (e.g., lung ovarian, } \\
\text { breast, prostate); } \\
\text { Clinical trials }\end{array}$ & Green tea & $\begin{array}{c}{[272-280,282-302,} \\
305,306]\end{array}$ \\
\hline . & $\begin{array}{c}\text { Cytostatic properties; } \\
\text { } \text { apoptosis; MDR modulation, } \\
\downarrow \text { MMPs; } \\
\downarrow \text { HDACs, DNMTs }\end{array}$ & $\begin{array}{l}\text { Laryngeal, pancreatic, brain, } \\
\text { kidney, breast, lung, bladder, } \\
\text { colorectal, prostate, head } \\
\text { and neck cancer, melanoma }\end{array}$ & Propolis & $\begin{array}{c}{[314,322,325,326,} \\
337-339]\end{array}$ \\
\hline $\begin{array}{l}\text { Cafteic acid phenethyl ester, } \\
\text { caffeic acid }\end{array}$ & & & & \\
\hline
\end{tabular}

\section{Conclusions}

Oncologists use a multidisciplinary approach to overcome cancers including surgical resection of tumors tissues, and radio- as well as chemotherapy. In many cases, surgery is the most substantial part of therapy and cytostatic agents or irradiation are often applied as an adjuvant or neoadjuvant treatment to increase effectiveness of the therapy and ensure better clinical prognosis. Nature has provided us with many substances displaying anticancer activity which have widely been applied in medicine, such as taxanes, vinca alkaloids, podophyllotoxin, camptothecin, anthracyclines, their derivatives and others [340]. In recent years, a vast number of natural compounds have been tested to 
establish their medical potential in cancer therapy [341]; however, only a small minority of these substances have qualified for clinical trials and treatment of cancer patients [26]. In recent years, polyphenols, (mostly green tea catechins) were investigated in patients suffering from prostate cancer; however, the collected data suggested that the action of the compounds was not directly aimed at cancer prevention [342]. On the other hand, green tea consumption does lower the risk of breast cancer [301]. Other clinical trials considering the described polyphenols included evaluation of ginger in colorectal cancer prevention. Additionally, some scientists studied the bioactivity of indole-3-carbinol from broccoli sprouts in preventing and treatment of breast, prostatic and pancreatic cancers [343,344]. The potential protective ability of phenetyl isothiocyanate against lung and prostate cancer or betulinic acid against cutaneous metastatic melanoma, has also been researched. Other clinical trials suggested that resveratrol might find an application in patients with colon cancers.

It is worth highlighting that more than half of cytostatics approved for medical treatment are nature-derived substances, their analogues and metabolites. Due to their non-selective activity and serious side effects, there is still a strong need to research and develop new medicines and substances of natural origin to improve human cancer treatment. The aforementioned agents present both low toxicity and potential selectivity against cancer cells. They are tolerable within the human organism even at high doses, in contrast to chemotherapeutics used in current cancer treatment. These substances may induce antimitotic activity via different mechanisms, particularly by disturbance of functionality of mitotic spindle or by inhibiting the activity of enzymes necessary in the DNA replication process. Some of these drugs may induce oxidative stress promoting cell death and limiting distant metastasis, affect activity of II phase enzymes, act as anti-angiogenic agents or inhibit cell migration. Additionally, some of those compounds may be used in photodynamic therapy or reversing of the multidrug resistance. Moreover, some studies suggest that the substances from medicinal plants prevent carcinogenesis [345], lower the risk of death and extend survival time among oncological patients [346]. Taking all this into account, and having in mind methods of increasing biodistribution of the agents (electroporation, sonoporation or encapsulation in special nanocarriers), they might become an interesting alternative to classical treatment. In some cases, synthetic modifications of these substances improve their anticancer activity, prolong their circulation time in the bloodstream or reduce toxicity [340]. Therefore, continued study using in vivo systems and improved clinical trials are necessary to establish the safety and clinical application of nature-derived medicines. Moreover, it is essential to use high-throughput drug screening technology such as NMR (nuclear magnetic resonance spectrometry), LC-MS (liquid chromatography-mass spectrometry), HPLC-MS (high-performance liquid chromatography-mass spectrometry) and others, to find new natural substances for forthcoming research [341]. Natural compounds remain an interesting tool in cancer treatment, thus we believe that more promising anticancer substances will be discovered which will allow for untapped scientific possibilities.

Author Contributions: J.S., J.K. and O.M. conceptualized and designed the study, writing-original draft preparation: D.P., M.J.N., S.S., A.G., K.K., P.R., K.W.; writing-review and editing, M.J.N., A.G., D.P., P.W., S.S., K.K., A.K., W.B.; visualization: A.G, D.P., P.R., K.W.; supervision: O.M., J.K., J.S.

Funding: The work was created as part of the activity of the Student Research Group "Biology of Cancer Cell" at the Wroclaw Medical University (SKN No. K 148). The research was supported partially by the Statutory Funds of Department of Molecular and Cellular Biology (PI: J. Saczko) and by "Najlepsi z Najlepszych 3.0" PO WER (2014-2020) (POWR.Z600.18.002.) programme founded by Polish Ministry of Science and Higher Education and partially by National Science Centre (Poland) within a framework of SONATA BIS 6 (2016/22/E/NZ5/00671; PI: J. Kulbacka).

Acknowledgments: We would also like to thank Jacob A. Cordova and Ashley M. Dennison for the correction of the English language in the manuscript.

Conflicts of Interest: The authors declare no conflict of interest. 


\section{References}

1. American Cancer Society. Cancer Facts E Figures 2018; American Cancer Society: Atlanta, GA, USA, 2018.

2. Prakash, O.; Kumar, A.; Kumar, P.; Ajeet, A. Anticancer Potential of Plants and Natural Products: A Review. Am. J. Pharmacol. Sci. 2013, 1, 104-115. [CrossRef]

3. Demain, A.L.; Vaishnav, P. Natural products for cancer chemotherapy. Microb. Biotechnol. 2011, 4, 687-699. [CrossRef] [PubMed]

4. Hanahan, D.; Weinberg, R.A. Hallmarks of cancer: The next generation. Cell 2011, 144, 646-674. [CrossRef] [PubMed]

5. Kelly, T.K.; De Carvalho, D.D.; Jones, P.A. Epigenetics Modifications as Therapeutic Targets. Nat. Biotechnol. 2010, 28, 1069. [CrossRef] [PubMed]

6. Putiri, E.L.; Robertson, K.D. Epigenetic mechanisms and genome stability. Clin. Epigenetics 2011, 2, $299-314$. [CrossRef] [PubMed]

7. Wang, Y.; Li, Y.; Liu, X.; Cho, W. Genetic and Epigenetic Studies for Determining Molecular Targets of Natural Product Anticancer Agents. Curr. Cancer Drug Targets 2013, 13, 506-518. [CrossRef] [PubMed]

8. Lichtenstein, A.V. Cancer: Evolutionary, genetic and epigenetic aspects. Clin. Epigenetics 2010, 1, 85-100. [CrossRef] [PubMed]

9. Tsai, H.C.; Baylin, S.B. Cancer epigenetics: Linking basic biology to clinical medicine. Cell Res. 2011, 21, 502-517. [CrossRef]

10. Huang, J.; Plass, C.; Gerhauser, C. Cancer chemoprevention by targeting the epigenome. Curr. Drug Targets 2011, 12, 1925-1956. [CrossRef]

11. Stefanska, B.; Karlic, H.; Varga, F.; Fabianowska-Majewska, K.; Haslberger, A.G. Epigenetic mechanisms in anti-cancer actions of bioactive food components - The implications in cancer prevention. Br. J. Pharmacol. 2012, 167, 279-297. [CrossRef]

12. Ratovitski, E. Anticancer Natural Compounds as Epigenetic Modulators of Gene Expression. Curr. Genom. 2017, 18, 175-205. [CrossRef] [PubMed]

13. Rajendran, P.; Ho, E.; Williams, D.E.; Dashwood, R.H. Dietary phytochemicals, HDAC inhibition, and DNA damage/repair defects in cancer cells. Clin. Epigenetics 2011, 3, 4. [CrossRef] [PubMed]

14. Gao, Y.; Tollefsbol, T. Impact of Epigenetic Dietary Components on Cancer through Histone Modifications. Curr. Med. Chem. 2015, 22, 2051-2064. [CrossRef] [PubMed]

15. Vahid, F.; Zand, H.; Nosrat-Mirshekarlou, E.; Najafi, R.; Hekmatdoost, A. The role dietary of bioactive compounds on the regulation of histone acetylases and deacetylases: A review. Gene 2015, 562, 8-15. [CrossRef] [PubMed]

16. Lim, U.; Song, M.-A. Dietary and lifestyle factors of DNA methylation. Methods Mol. Biol. 2012, 863, 359-376. [PubMed]

17. Li, Y.; Tollefsbol, T.O. Impact on DNA Methylation in Cancer Prevention and Therapy by Bioactive Dietary Components. Curr. Med. Chem. 2010, 17, 2141-2151. [CrossRef] [PubMed]

18. Kong, A.-N.T.; Zhang, C.; Su, Z.-Y. Targeting Epigenetics for Cancer Prevention By Dietary Cancer Preventive Compounds-The Case of miRNA. Cancer Prev. Res. 2013, 6, 622-624. [CrossRef] [PubMed]

19. Phuah, N.H.; Nagoor, N.H. Regulation of MicroRNAs by Natural Agents: A New Strategies in Cancer Therapies. Biomed. Res. Int. 2014, 2014, 804510. [CrossRef]

20. Lin, Q.; Ma, L.; Liu, Z.; Yang, Z.; Wang, J.; Liu, J.; Jiang, G. Targeting microRNAs: A new action mechanism of natural compounds. Oncotarget 2017, 8, 15961-15970. [CrossRef]

21. Shankar, S.; Kumar, D.; Srivastava, R.K. Epigenetic modifications by dietary phytochemicals: Implications for personalized nutrition. Pharmacol. Ther. 2013, 138, 1-17. [CrossRef]

22. Li, Y.; Sarkar, F.H. Targeting Epigenetically Deregulated miRNA by Nutraceuticals: Focusing on Cancer Prevention and Treatment. Curr. Pharmacol. Rep. 2015, 1, 1-10. [CrossRef]

23. De Kok, T.M.; van Breda, S.G.; Briedé, J.J. Genomics-Based Identification of Molecular Mechanisms behind the Cancer Preventive Action of Phytochemicals: Potential and Challenges. Curr. Pharm. Biotechnol. 2012, 13, 255-264. [CrossRef]

24. Baylin, S.B.; Jones, P.A. A decade of exploring the cancer epigenome-Biological and translational implications. Nat. Rev. Cancer 2011, 11, 726-734. [CrossRef] [PubMed] 
25. Plass, C.; Pfister, S.M.; Lindroth, A.M.; Bogatyrova, O.; Claus, R.; Lichter, P. Mutations in regulators of the epigenome and their connections to global chromatin patterns in cancer. Nat. Rev. Genet. 2013, 14,765-780. [CrossRef]

26. Sarwar, M.S.; Zhang, H.-J.; Tsang, S.W. Perspectives of Plant Natural Products in Inhibition of Cancer Invasion and Metastasis by Regulating Multiple Signaling Pathways. Curr. Med. Chem. 2018, 25, 5057-5087. [CrossRef]

27. Gascoigne, K.E.; Taylor, S.S. How do anti-mitotic drugs kill cancer cells? J. Cell Sci. 2009, 122, $2579-2585$. [CrossRef]

28. Jordan, M.A.; Wilson, L. Microtubules as a target for anticancer drugs. Nat. Rev. Cancer 2004, 4, $253-265$. [CrossRef]

29. Najem, S.; Langemann, D.; Appl, B.; Trochimiuk, M.; Hundsdoerfer, P.; Reinshagen, K.; Eschenburg, G. Smac mimetic LCL161 supports neuroblastoma chemotherapy in a drug class-dependent manner and synergistically interacts with ALK inhibitor TAE684 in cells with ALK mutation F1174L. Oncotarget 2016, 7, 72634-72653. [CrossRef]

30. Zhu, R.-H.; Li, H.-D.; Cai, H.-L.; Jiang, Z.-P.; Xu, P.; Dai, L.-B.; Peng, W.-X. Validated HILIC-MS/MS assay for determination of vindesine in human plasma: Application to a population pharmacokinetic study. J. Pharm. Biomed. Anal. 2014, 96, 31-36. [CrossRef]

31. Almagro, L. Indole Alkaloids from Catharanthus roseus: Bioproduction and Their Effect on Human Health. Molecules 2015, 20, 2973-3000. [CrossRef]

32. Rowinsky, E. The Vinca Alkaloids. In Holland-Frei Cancer Medicine, 6th ed.; BC Decker: Hamilton, ON, Canada, 2003.

33. Mukhtar, E.; Adhami, V.M.; Mukhtar, H. Targeting microtubules by natural agents for cancer therapy. Mol. Cancer Ther. 2014, 13, 275-284. [CrossRef]

34. Glikokoniugatów, Z.B.; Zoologii, I. Substancje pochodzenia roślinnego w terapii nowotworów Plant-derived compounds in the treatment of cancer. Postępy Fitoterapii 2017, 18, 203-208.

35. Moudi, M.; Go, R.; Yien, C.Y.S.; Nazre, M. Vinca alkaloids. Int. J. Prev. Med. 2013, 4, 1231-1235.

36. Allen, T.M.; Cullis, P.R. Liposomal drug delivery systems: From concept to clinical applications. Adv. Drug Deliv. Rev. 2013, 65, 36-48. [CrossRef]

37. Lee, C.-T.; Huang, Y.-W.; Yang, C.-H.; Huang, K.-S. Drug delivery systems and combination therapy by using vinca alkaloids. Curr. Top. Med. Chem. 2015, 15, 1491-1500. [CrossRef]

38. Slobodnick, A.; Shah, B.; Pillinger, M.H.; Krasnokutsky, S. Colchicine: Old and New. Am. J. Med. 2015, 128, 461-470. [CrossRef]

39. Dalbeth, N.; Lauterio, T.J.; Wolfe, H.R. Mechanism of action of colchicine in the treatment of gout. Clin. Ther. 2014, 36, 1465-1479. [CrossRef]

40. Ben-Chetrit, E.; Bergmann, S.; Sood, R. Mechanism of the anti-inflammatory effect of colchicine in rheumatic diseases: A possible new outlook through microarray analysis. Rheumatology 2006, 45, 274-282. [CrossRef]

41. Özkaya, N.; Yalçinkaya, F. Colchicine treatment in children with familial Mediterranean fever. Clin. Rheumatol. 2003, 22, 314-317. [CrossRef]

42. Leung, Y.Y.; Yao Hui, L.L.; Kraus, V.B. Colchicine-Update on mechanisms of action and therapeutic uses. Semin. Arthritis Rheum. 2015, 45, 341-350. [CrossRef]

43. Lu, Y.; Chen, J.; Xiao, M.; Li, W.; Miller, D.D. An overview of tubulin inhibitors that interact with the colchicine binding site. Pharm. Res. 2012, 29, 2943-2971. [CrossRef]

44. Maldonado, E.N.; Patnaik, J.; Mullins, M.R.; Lemasters, J.J. Free Tubulin Modulates Mitochondrial Membrane Potential in Cancer Cells. Cancer Res. 2011, 70, 10192-10201. [CrossRef]

45. Lin, Z.-Y.; Kuo, C.-H.; Wu, D.-C.; Chuang, W.-L. Anticancer effects of clinically acceptable colchicine concentrations on human gastric cancer cell lines. Kaohsiung J. Med. Sci. 2016, 32, 68-73. [CrossRef]

46. Banerjee, S.; Hwang, D.J.; Li, W.; Miller, D.D. Current Advances of Tubulin Inhibitors in Nanoparticle Drug Delivery and Vascular Disruption/Angiogenesis. Molecules 2016, 21, 1468. [CrossRef]

47. Tangutoori, S.; Ohta, A.; Gatley, S.; Campbell, R.B. Repurposing an Erstwhile Cancer Drug: A Quantitative and Therapeutic Evaluation of Alternative Nanosystems for the Delivery of Colchicine to Solid Tumors. J. Cancer Sci. Ther. 2014, 6, 236-246. [CrossRef]

48. Hearn, B.R.; Shaw, S.J.; Myles, D.C. Microtubule Targeting Agents. In Comprehensive Medicinal Chemistry II; Elsevier: Amsterdam, The Netherlands, 2007; pp. 81-110. ISBN 9780080450445. 
49. Zygadlo, J.A.; Gleiser, R.M. Chemical Ecology in Relation to Medicine and Pharmaceuticals. In Chemical Ecology; EOLSS Publications: Oxford, UK, 2009; pp. 491-504.

50. Kumar, A.; Kumar, V.; Alegria, A.E.; Malhotra, S.V. Synthetic and application perspectives of azapodophyllotoxins: Alternative scaffolds of podophyllotoxin. Curr. Med. Chem. 2011, 18, 3853-3870. [CrossRef]

51. Ardalani, H. Podophyllotoxin: A novel potential natural anticancer agent. Avicenna J. Phytomed. 2017, 7, 285-294.

52. The Royal Society Of Chemistry ChemSpider. Search and Share Chemistry. Available online: http://www.chemspider. $\mathrm{com} /$ (accessed on 25 March 2019).

53. Rai, V.; Tandon, P.K.; Khatoon, S. Effect of chromium on antioxidant potential of Catharanthus roseus varieties and production of their anticancer alkaloids: Vincristine and vinblastine. Biomed. Res. Int. 2014, 2014, 934182. [CrossRef]

54. Aapro, M.; Finek, J. Oral vinorelbine in metastatic breast cancer: A review of current clinical trial results. Cancer Treat. Rev. 2012, 38, 120-126. [CrossRef]

55. Gerullis, H.; Wawroschek, F.; Köhne, C.-H.; Ecke, T.H. Vinflunine in the treatment of advanced urothelial cancer: Clinical evidence and experience. Ther. Adv. Urol. 2017, 9, 28-35. [CrossRef]

56. Cortés, F.; Pastor, N.; Mateos, S.; Domínguez, I. Roles of DNA topoisomerases in chromosome segregation and mitosis. Mutat. Res. Rev. Mutat. Res. 2003, 543, 59-66. [CrossRef]

57. Mittal, B.; Tulsyan, S.; Kumar, S.; Mittal, R.D.; Agarwal, G. Cytochrome P450 in Cancer Susceptibility and Treatment; Elsevier: Amsterdam, The Netherlands, 2015; ISBN 9780128022566.

58. Hande, K.R. Etoposide: Four decades of development of a topoisomerase II inhibitor. Eur. J. Cancer 1998, 34, 1514-1521. [CrossRef]

59. Smith, M.A. Etoposide and Teniposide. W Treatment of Acute Leukemias; Humana Press: Totowa, NJ, USA, 2003; pp. 429-437.

60. Young, R.C. Etoposide in the treatment of non-Hodgkin's lymphomas. Semin. Oncol. 1992, 19, 19-25.

61. Hande, K.R. Topoisomerase II inhibitors. Update Cancer Ther. 2008, 3, 13-26. [CrossRef]

62. Stanton, R.A.; Gernert, K.M.; Nettles, J.H.; Aneja, R. Drugs That Target Dynamic Microtubules: A New Molecular Perspective. Med. Res. Rev. 2011, 31, 443-481. [CrossRef]

63. Schwab, C.L.; English, D.P.; Roque, D.M.; Santin, A.D. Taxanes: Their impact on gynecologic malignancy. Anticancer. Drugs 2014, 25, 522-535. [CrossRef]

64. Markman, M.; Mekhail, T.M. Paclitaxel in cancer therapy. Expert Opin. Pharmacother. 2002, 3, 755-766. [CrossRef]

65. Prabhash, K.; Noronha, V.; Patil, V.; Bhosale, B.; Joshi, A.; Purandare, N. Metronomic weekly paclitaxel in advanced unresectable esophageal cancer. Indian J. Cancer 2013, 50, 128. [CrossRef]

66. Yared, J.A.; Tkaczuk, K.H.R. Update on taxane development: New analogs and new formulations. Drug Des. Dev. Ther. 2012, 6, 371-384.

67. Rowinsky, E.K. The development and clinical utility of the taxane class of antimicrotubule chemotherapy agents. Annu. Rev. Med. 1997, 48, 353-374. [CrossRef]

68. Zhang, D.; Yang, R.; Wang, S.; Dong, Z. Paclitaxel: New uses for an old drug. Drug Des. Dev. Ther. 2014, 8, 279-284.

69. Crown, J.; O'Leary, M.; Ooi, W.-S. Docetaxel and paclitaxel in the treatment of breast cancer: A review of clinical experience. Oncologist 2004, 9 (Suppl. 2), 24-32. [CrossRef]

70. Katsumata, N. Docetaxel: An alternative taxane in ovarian cancer. Br. J. Cancer 2003, 89, S9-S15. [CrossRef] [PubMed]

71. Nabell, L.; Spencer, S. Docetaxel with concurrent radiotherapy in head and neck cancer. Semin. Oncol. 2003, 30, 89-93. [CrossRef] [PubMed]

72. Heys, S.D.; Sarkar, T.; Hutcheon, A.W. Primary docetaxel chemotherapy in patients with breast cancer: Impact on response and survival. Breast Cancer Res. Treat. 2005, 90, 169-185. [CrossRef] [PubMed]

73. He, X.; Wang, J.; Li, Y. Efficacy and safety of docetaxel for advanced non-small-cell lung cancer: A meta-analysis of phase iii randomized controlled trials. OncoTargets Ther. 2015, 8, 2023-2031. [CrossRef] [PubMed]

74. Tetzlaff, E.D.; Cheng, J.D.; Ajani, J.A. Review of docetaxel in the treatment of gastric cancer. Ther. Clin. Risk Manag. 2008, 4, 999-1007. [CrossRef] [PubMed] 
75. Albany, C.; Sonpavde, G. Docetaxel for the treatment of bladder cancer. Expert Opin. Investig. Drugs 2015, 24, 1657-1664. [CrossRef] [PubMed]

76. Alberts, B.; Johnson, A.; Lewis, J.; Raff, M.; Roberts, K.; Walter, P. Molecular Biology of the Cell; Garland Science: Boca Raton, FL, USA, 2002; ISBN 0815332181.

77. Pommier, Y. DNA topoisomerase I inhibitors: Chemistry, biology, and interfacial inhibition. Chem. Rev. 2009, 109, 2894-2902. [CrossRef] [PubMed]

78. Wieczorek, M.; Sobiak, S.; Meissner, R.K. Rozwój badań nad wykorzystaniem substancji pochodzenia roślinnego w terapii nowotworów. Now. Lek. 2006, 75, 407-413.

79. O'Reilly, S.; Rowinsky, E.K. The clinical status of irinotecan (CPT-11), a novel water soluble camptothecin analogue: 1996. Crit. Rev. Oncol. Hematol. 1996, 24, 47-70. [CrossRef]

80. Creemers, G.J.; Wanders, J.; Gamucci, T.; Vallentin, S.; Dirix, L.Y.; Schöffski, P.; Hudson, I.; Verweij, J. Topotecan in colorectal cancer: A phase II study of the EORTC early clinical trials group. Ann. Oncol. 1995, 6, 844-846. [CrossRef] [PubMed]

81. Sevinc, A.; Kalender, M.E.; Altinbas, M.; Ozkan, M.; Dikilitas, M.; Camci, C.; Anatolian Society of Medical Oncology (ASMO). Irinotecan as a second-line monotherapy for small cell lung cancer. Asian Pac. J. Cancer Prev. 2011, 12, 1055-1059. [PubMed]

82. Wu, G.; Qi, X.; Mo, X.; Yu, G.; Wang, Q.; Zhu, T.; Gu, Q.; Liu, M.; Li, J.; Li, D. Structure-based discovery of cytotoxic dimeric tetrahydroxanthones as potential topoisomerase I inhibitors from a marine-derived fungus. Eur. J. Med. Chem. 2018, 148, 268-278. [CrossRef] [PubMed]

83. Rosen, L.S. Irinotecan in lymphoma, leukemia, and breast, pancreatic, ovarian, and small-cell lung cancers. Oncology 1998, 12, 103-109. [PubMed]

84. Gerrits, C.J.; Burris, H.; Schellens, J.H.; Planting, A.S.; van den Burg, M.E.; Rodriguez, G.; van Beurden, V.; Loos, W.; Hudson, I.; Fields, S. Five days of oral topotecan (hycamtin ${ }^{\circledR}$ ), a phase I and pharmacological study in adult patients with solid tumours. Eur. J. Cancer 1998, 34, 1030-1035. [CrossRef]

85. Björkholm, M. Etoposide and teniposide in the treatment of acute leukemia. Med. Oncol. Tumor Pharmacother. 1990, 7, 3-10.

86. Slevin, M.L.; Clark, P.I.; Joel, S.P.; Malik, S.; Osborne, R.J.; Gregory, W.M.; Lowe, D.G.; Reznek, R.H.; Wrigley, P.F. A randomized trial to evaluate the effect of schedule on the activity of etoposide in small-cell lung cancer. J. Clin. Oncol. 1989, 7, 1333-1340. [CrossRef]

87. Loehrer, P.J. Etoposide therapy for testicular cancer. Cancer 1991, 67, 220-224. [CrossRef]

88. Taylor, R.E.; McElwain, T.J.; Barrett, A.; Peckham, M.J. Etoposide as a single agent in relapsed advanced lymphomas. Cancer Chemother. Pharmacol. 1982, 7, 175-177. [CrossRef]

89. Sheweita, S.A.; Tilmisany, A.K. Cancer and phase II drug-metabolizing enzymes. Curr. Drug Metab. 2003, 4, 45-58. [CrossRef] [PubMed]

90. Croom, E. Metabolism of Xenobiotics of Human Environments. In Progress in Molecular Biology and Translational Science; Academic Press: Cambridge, MA, USA, 2012; pp. 31-88.

91. Hayes, J.D.; Flanagan, J.U.; Jowsey, I.R. Glutatione transperases. Annu. Rev. Pharmacol. Toxicol. 2005, 45, 51-88. [CrossRef] [PubMed]

92. Usta, M.; Wortelboer, H.M.; Vervoort, J.; Boersma, M.G.; Rietjens, I.M.C.M.; van Bladeren, P.J.; Cnubben, N.H.P. Human Glutathione S-Transferase-Mediated Glutathione Conjugation of Curcumin and Efflux of These Conjugates in Caco-2 Cells. Chem. Res. Toxicol. 2007, 20, 1895-1902. [CrossRef] [PubMed]

93. Tew, K.D.; Manevich, Y.; Grek, C.; Xiong, Y.; Uys, J.; Townsend, D.M. The role of glutathione S-transferase P in signaling pathways and S-glutathionylation in cancer. Free Radic. Biol. Med. 2011, 51, 299-313. [CrossRef] [PubMed]

94. Ross, D. Quinone Reductases Multitasking in the Metabolic World. Drug Metab. Rev. 2004, 36, 639-654. [CrossRef] [PubMed]

95. Siegel, D.; Kepa, J.K.; Ross, D. Biochemical and Genetic Analysis of NAD(P)H:Quinone Oxidoreductase 1 (NQO1). In Current Protocols in Toxicology; John Wiley \& Sons, Inc.: Hoboken, NJ, USA, 2007; Chapter 4; p. Unit4.22.

96. Osman, A.G.; Chittiboyina, A.G.; Khan, I.A. Cytoprotective Role of Dietary Phytochemicals Against Cancer Development via Induction of Phase II and Antioxidant Enzymes. Adv. Mol. Toxicol. 2016, 10, 99-137.

97. Talalay, P. Chemoprotection against cancer by induction of phase 2 enzymes. Biofactors 2000, 12, 5-11. [CrossRef] [PubMed] 
98. Krajka-Kuźniak, V. Induction of phase II enzymes as a strategy in the chemoprevention of cancer and other degenerative diseases. Postepy Hig. Med. Dosw. 2007, 61, 627-638.

99. Begleiter, A.; Leith, M.K.; Curphey, T.J.; Doherty, G.P. Induction of DT-diaphorase in cancer chemoprevention and chemotherapy. Oncol. Res. 1997, 9, 371-382.

100. González-Burgos, E.; Gómez-Serranillos, M.P. Terpene compounds in nature: A review of their potential antioxidant activity. Curr. Med. Chem. 2012, 19, 5319-5341. [CrossRef]

101. Sasaki, S.; Tozawa, T.; Sugamoto, K.; Matsushita, Y.; Satoh, T. A novel di terpene para-hydroquinone compound derived from cryptoquinone protects neuronal cells against oxidative stress and activates the Nrf2/ARE pathway. Neurosci. Lett. 2013, 548, 132-136. [CrossRef] [PubMed]

102. Ma, Q. Role of nrf2 in oxidative stress and toxicity. Annu. Rev. Pharmacol. Toxicol. 2013, 53, 401-426. [CrossRef] [PubMed]

103. Cavin, C.; Bezencon, C.; Guignard, G.; Schilter, B. Coffee diterpenes prevent benzo[a]pyrene genotoxicity in rat and human culture systems. Biochem. Biophys. Res. Commun. 2003, 306, 488-495. [CrossRef]

104. Huber, W.W.; Prustomersky, S.; Delbanco, E.; Uhl, M.; Scharf, G.; Turesky, R.J.; Thier, R.; Schulte-Hermann, R. Enhancement of the chemoprotective enzymes glucuronosyl transferase and glutathione transferase in specific organs of the rat by the coffee components kahweol and cafestol. Arch. Toxicol. 2002, 76, 209-217. [CrossRef] [PubMed]

105. García-Piñeres , A.; Lindenmeyer, M.; Merfort, I. Role of cysteine residues of p65/NF- $\kappa B$ on the inhibition by the sesquiterpene lactone parthenolide and N-ethyl maleimide, and on its transactivating potential. Life Sci. 2004, 75, 841-856. [CrossRef]

106. Guzman, M.L. The sesquiterpene lactone parthenolide induces apoptosis of human acute myelogenous leukemia stem and progenitor cells. Blood 2005, 105, 4163-4169. [CrossRef]

107. Woynarowski, J.M.; Konopa, J. Inhibition of DNA biosynthesis in HeLa cells by cytotoxic and antitumor sesquiterpene lactones. Mol. Pharmacol. 1981, 19, 97-102.

108. Pajak, B.; Gajkowska, B.; Orzechowski, A. Molecular basis of parthenolide-dependent proapoptotic activity in cancer cells. Folia Histochem. Cytobiol. 2008, 46, 129-135. [CrossRef]

109. Gopal, Y.N.V.; Chanchorn, E.; Van Dyke, M.W. Parthenolide promotes the ubiquitination of MDM2 and activates p53 cellular functions. Mol. Cancer Ther. 2009, 8, 552-562. [CrossRef]

110. Gopal, Y.N.V.; Arora, T.S.; Van Dyke, M.W. Parthenolide Specifically Depletes Histone Deacetylase 1 Protein and Induces Cell Death through Ataxia Telangiectasia Mutated. Chem. Biol. 2007, 14, 813-823. [CrossRef]

111. Liu, Z.; Liu, S.; Xie, Z.; Pavlovicz, R.E.; Wu, J.; Chen, P.; Aimiuwu, J.; Pang, J.; Bhasin, D.; Neviani, P. Modulation of DNA Methylation by a Sesquiterpene Lactone Parthenolide. J. Pharmacol. Exp. Ther. 2009, 329, 505-514. [CrossRef] [PubMed]

112. Xu, T.; Pang, Q.; Zhou, D.; Zhang, A.; Luo, S.; Wang, Y.; Yan, X. Proteomic investigation into betulinic acid-induced apoptosis of human cervical cancer HeLa cells. PLoS ONE 2014, 9, e105768. [CrossRef] [PubMed]

113. Tan, Y.; Yu, R.; Pezzuto, J.M. Betulinic acid-induced programmed cell death in human melanoma cells involves mitogen-activated protein kinase activation. Clin. Cancer Res. 2003, 9, 2866-2875. [PubMed]

114. Alakurtti, S.; Mäkelä, T.; Koskimies, S.; Yli-Kauhaluoma, J. Pharmacological properties of the ubiquitous natural product betulin. Eur. J. Pharm. Sci. 2006, 29, 1-13. [CrossRef] [PubMed]

115. Fulda, S.; Scaffidi, G.; Susin, S.A.; Krammer, P.H.; Kroemer, G.; Peter, M.E.; Debatin, K.M. Activation of mitochondria and release of mitochondrial apoptogenic factors by betulinic acid. J. Biol. Chem. 1998, 273, 33942-33948. [CrossRef] [PubMed]

116. Fulda, S.; Debatin, K.-M. Sensitization for anticancer drug-induced apoptosis by betulinic Acid. Neoplasia 2005, 7, 162-170. [CrossRef]

117. Sawada, N.; Kataoka, K.; Kondo, K.; Arimochi, H.; Fujino, H.; Takahashi, Y.; Miyoshi, T.; Kuwahara, T.; Monden, Y.; Ohnishi, Y. Betulinic acid augments the inhibitory effects of vincristine on growth and lung metastasis of B16F10 melanoma cells in mice. Br. J. Cancer 2004, 90, 1672-1678. [CrossRef] [PubMed]

118. Kostova, I.; Bhatia, S.; Grigorov, P.; Balkansky, S.; Parmar, V.S.; Prasad, A.K.; Saso, L. Coumarins as antioxidants. Curr. Med. Chem. 2011, 18, 3929-3951. [CrossRef]

119. Murakami, A.; Kuki, W.; Takahashi, Y.; Yonei, H.; Nakamura, Y.; Ohto, Y.; Ohigashi, H.; Koshimizu, K. Auraptene, a citrus coumarin, inhibits 12-O-tetradecanoylphorbol-13-acetate-induced tumor promotion in 
ICR mouse skin, possibly through suppression of superoxide generation in leukocytes. Jpn. J. Cancer Res. 1997, 88, 443-452. [CrossRef]

120. Tanaka, T.; Kawabata, K.; Kakumoto, M.; Hara, A.; Murakami, A.; Kuki, W.; Takahashi, Y.; Yonei, H.; Maeda, M.; Ota, T. Citrus auraptene exerts dose-dependent chemopreventive activity in rat large bowel tumorigenesis: The inhibition correlates with suppression of cell proliferation and lipid peroxidation and with induction of phase II drug-metabolizing enzymes. Cancer Res. 1998, 58, 2550-2556.

121. Aras, U.; Gandhi, Y.A.; Masso-Welch, P.A.; Morris, M.E. Chemopreventive and anti-angiogenic effects of dietary phenethyl isothiocyanate in an N-methyl nitrosourea-induced breast cancer animal model. Biopharm. Drug Dispos. 2013, 34, 98-106. [CrossRef] [PubMed]

122. Ni, W.-Y.; Lu, H.-F.; Hsu, S.-C.; Hsiao, Y.-P.; Liu, K.-C.; Liu, J.-Y.; Ji, B.-C.; Hsueh, S.-C.; Hung, F.-M.; Shang, H.-S. Phenethyl isothiocyanate inhibits in vivo growth of subcutaneous xenograft tumors of human malignant melanoma A375.S2 cells. In Vivo 2014, 28, 891-894. [PubMed]

123. Huang, S.-H.; Hsu, M.-H.; Hsu, S.-C.; Yang, J.-S.; Huang, W.-W.; Huang, A.-C.; Hsiao, Y.-P.; Yu, C.-C.; Chung, J.-G. Phenethyl isothiocyanate triggers apoptosis in human malignant melanoma A375.S2 cells through reactive oxygen species and the mitochondria-dependent pathways. Hum. Exp. Toxicol. 2014, 33, 270-283. [CrossRef] [PubMed]

124. Moon, Y.J.; Brazeau, D.A.; Morris, M.E. Dietary phenethyl isothiocyanate alters gene expression in human breast cancer cells. Evid. Based Complement. Alternat. Med. 2011, 2011, 462525. [CrossRef] [PubMed]

125. Yan, H.; Zhu, Y.; Liu, B.; Wu, H.; Li, Y.; Wu, X.; Zhou, Q.; Xu, K. Mitogen-activated protein kinase mediates the apoptosis of highly metastatic human non-small cell lung cancer cells induced by isothiocyanates. Br. J. Nutr. 2011, 106, 1779-1791. [CrossRef] [PubMed]

126. Wang, X.; Govind, S.; Sajankila, S.P.; Mi, L.; Roy, R.; Chung, F.-L. Phenethyl isothiocyanate sensitizes human cervical cancer cells to apoptosis induced by cisplatin. Mol. Nutr. Food Res. 2011, 55, 1572-1581. [CrossRef] [PubMed]

127. Wu, C.-L.; Huang, A.-C.; Yang, J.-S.; Liao, C.-L.; Lu, H.-F.; Chou, S.-T.; Ma, C.-Y.; Hsia, T.-C.; Ko, Y.-C.; Chung, J.-G. Benzyl isothiocyanate (BITC) and phenethyl isothiocyanate (PEITC)-mediated generation of reactive oxygen species causes cell cycle arrest and induces apoptosis via activation of caspase-3, mitochondria dysfunction and nitric oxide (NO) in human osteogenic. J. Orthop. Res. 2011, 29, 1199-1209. [CrossRef] [PubMed]

128. Xiao, D.; Powolny, A.A.; Moura, M.B.; Kelley, E.E.; Bommareddy, A.; Kim, S.-H.; Hahm, E.-R.; Normolle, D.; Van Houten, B.; Singh, S. V Phenethyl isothiocyanate inhibits oxidative phosphorylation to trigger reactive oxygen species-mediated death of human prostate cancer cells. J. Biol. Chem. 2010, 285, 26558-26569. [CrossRef]

129. Jakubikova, J.; Cervi, D.; Ooi, M.; Kim, K.; Nahar, S.; Klippel, S.; Cholujova, D.; Leiba, M.; Daley, J.F.; Delmore, J. Anti-tumor activity and signaling events triggered by the isothiocyanates, sulforaphane and phenethyl isothiocyanate, in multiple myeloma. Haematologica 2011, 96, 1170-1179. [CrossRef]

130. Chou, Y.-C.; Chang, M.-Y.; Wang, M.-J.; Harnod, T.; Hung, C.-H.; Lee, H.-T.; Shen, C.-C.; Chung, J.-G. PEITC induces apoptosis of Human Brain Glioblastoma GBM8401 Cells through the extrinsic- and intrinsic -signaling pathways. Neurochem. Int. 2015, 81, 32-40. [CrossRef]

131. Wang, L.G.; Beklemisheva, A.; Liu, X.M.; Ferrari, A.C.; Feng, J.; Chiao, J.W. Dual action on promoter demethylation and chromatin by an isothiocyanate restored GSTP1 silenced in prostate cancer. Mol. Carcinog. 2007, 46, 24-31. [CrossRef]

132. Boyanapalli, S.S.S.; Li, W.; Fuentes, F.; Guo, Y.; Ramirez, C.N.; Gonzalez, X.-P.; Pung, D.; Kong, A.-N.T. Epigenetic reactivation of RASSF1A by phenethyl isothiocyanate (PEITC) and promotion of apoptosis in LNCaP cells. Pharmacol. Res. 2016, 114, 175-184. [CrossRef]

133. Lea, M.A.; Randolph, V.M.; Lee, J.E.; DesBordes, C. Induction of histone acetylation in mouse erythroleukemia cells by some organosulfur compounds including allyl isothiocyanate. Int. J. Cancer 2001, 92, 784-789. [CrossRef] [PubMed]

134. Izzotti, A.; Calin, G.A.; Steele, V.E.; Cartiglia, C.; Longobardi, M.; Croce, C.M.; De Flora, S. Chemoprevention of Cigarette Smoke-Induced Alterations of MicroRNA Expression in Rat Lungs. Cancer Prev. Res. 2010, 3, 62-72. [CrossRef] [PubMed] 
135. Izzotti, A.; Larghero, P.; Cartiglia, C.; Longobardi, M.; Pfeffer, U.; Steele, V.E.; De Flora, S. Modulation of microRNA expression by budesonide, phenethyl isothiocyanate and cigarette smoke in mouse liver and lung. Carcinogenesis 2010, 31, 894-901. [CrossRef] [PubMed]

136. Zhang, C.; Shu, L.; Kim, H.; Khor, T.O.; Wu, R.; Li, W.; Kong, A.-N.T. Phenethyl isothiocyanate (PEITC) suppresses prostate cancer cell invasion epigenetically through regulating microRNA-194. Mol. Nutr. Food Res. 2016, 60, 1427-1436. [CrossRef] [PubMed]

137. van Lieshout, E.M.; Bedaf, M.M.; Pieter, M.; Ekkel, C.; Nijhoff, W.A.; Peters, W.H. Effects of dietary anticarcinogens on rat gastrointestinal glutathione S-transferase theta 1-1 levels. Carcinogenesis 1998, 19, 2055-2057. [CrossRef] [PubMed]

138. FIMOGNARI, C.; HRELIA, P. Sulforaphane as a promising molecule for fighting cancer. Mutat. Res. Mutat. Res. 2007, 635, 90-104. [CrossRef] [PubMed]

139. Li, Y.; Zhang, T.; Korkaya, H.; Liu, S.; Lee, H.F.; Newman, B.; Yu, Y.; Clouthier, S.G.; Schwartz, S.J.; Wicha, M.S. Sulforaphane, a Dietary Component of Broccoli/Broccoli Sprouts, Inhibits Breast Cancer Stem Cells. Clin. Cancer Res. 2010, 16, 2580-2590. [CrossRef] [PubMed]

140. Clarke, J.D.; Dashwood, R.H.; Ho, E. Multi-targeted prevention of cancer by sulforaphane. Cancer Lett. 2008, 269, 291-304. [CrossRef]

141. Mahéo, K.; Morel, F.; Langouët, S.; Kramer, H.; Le Ferrec, E.; Ketterer, B.; Guillouzo, A. Inhibition of cytochromes P-450 and induction of glutathione S-transferases by sulforaphane in primary human and rat hepatocytes. Cancer Res. 1997, 57, 3649-3652. [PubMed]

142. Abdull Razis, A.F.; Noor, N.M. Sulforaphane is superior to glucoraphanin in modulating carcinogen-metabolising enzymes in Hep G2 cells. Asian Pac. J. Cancer Prev. 2013, 14, 4235-4238. [CrossRef] [PubMed]

143. Fahey, J.W.; Holtzclaw, W.D.; Wehage, S.L.; Wade, K.L.; Stephenson, K.K.; Talalay, P. Sulforaphane Bioavailability from Glucoraphanin-Rich Broccoli: Control by Active Endogenous Myrosinase. PLoS ONE 2015, 10, e0140963. [CrossRef] [PubMed]

144. Shapiro, T.A.; Fahey, J.W.; Dinkova-Kostova, A.T.; Holtzclaw, W.D.; Stephenson, K.K.; Wade, K.L.; Ye, L.; Talalay, P. Safety, Tolerance, and Metabolism of Broccoli Sprout Glucosinolates and Isothiocyanates: A Clinical Phase I Study. Nutr. Cancer 2006, 55, 53-62. [CrossRef] [PubMed]

145. Mut-Salud, N.; Álvarez, P.J.; Garrido, J.M.; Carrasco, E.; Aránega, A.; Rodríguez-Serrano, F. Antioxidant Intake and Antitumor Therapy: Toward Nutritional Recommendations for Optimal Results. Oxid. Med. Cell. Longev. 2016, 2016, 6719534. [CrossRef] [PubMed]

146. Guyonnet, D.; Belloir, C.; Suschetet, M.; Siess, M.H.; Le Bon, A.M. Antimutagenic activity of organosulfur compounds from Allium is associated with phase II enzyme induction. Mutat. Res. 2001, 495, 135-145. [CrossRef]

147. Munday, R.; Munday, J.S.; Munday, C.M. Comparative effects of mono-, di-, tri-, and tetrasulfides derived from plants of the Allium family: Redox cycling in vitro and hemolytic activity and Phase 2 enzyme induction in vivo. Free Radic. Biol. Med. 2003, 34, 1200-1211. [CrossRef]

148. Guyonnet, D.; Siess, M.-H.; Le Bon, A.-M.; Suschetet, M. Modulation of Phase II Enzymes by Organosulfur Compounds from Allium Vegetables in Rat Tissues. Toxicol. Appl. Pharmacol. 1999, 154, 50-58. [CrossRef]

149. Lea, M.A.; Rasheed, M.; Randolph, V.M.; Khan, F.; Shareef, A.; DesBordes, C. Induction of Histone Acetylation and Inhibition of Growth of Mouse Erythroleukemia Cells by S-Allylmercaptocysteine. Nutr. Cancer 2002, 43, 90-102. [CrossRef]

150. DRUESNE, N.; PAGNIEZ, A.; MAYEUR, C.; THOMAS, M.; CHERBUY, C.; DUÉE, P.-H.; MARTEL, P.; CHAUMONTET, C. Repetitive Treatments of Colon HT-29 Cells with Diallyl Disulfide Induce a Prolonged Hyperacetylation of Histone H3 K14. Ann. N. Y. Acad. Sci. 2004, 1030, 612-621. [CrossRef]

151. Nian, H.; Delage, B.; Ho, E.; Dashwood, R.H. Modulation of histone deacetylase activity by dietary isothiocyanates and allyl sulfides: Studies with sulforaphane and garlic organosulfur compounds. Environ. Mol. Mutagen. 2009, 50, 213-221. [CrossRef] [PubMed]

152. Lea, M.A.; Randolph, V.M.; Patel, M. Increased acetylation of histones induced by diallyl disulfide and structurally related molecules. Int. J. Oncol. 1999, 15, 347-399. [CrossRef]

153. Druesne, N. Diallyl disulfide (DADS) increases histone acetylation and p21waf1/cip1 expression in human colon tumor cell lines. Carcinogenesis 2004, 25, 1227-1236. [CrossRef] [PubMed] 
154. Busbee, P.B.; Nagarkatti, M.; Nagarkatti, P.S. Natural indoles, indole-3-carbinol (I3C) and 3,3'-diindolylmethane (DIM), attenuate staphylococcal enterotoxin B-mediated liver injury by downregulating miR-31 expression and promoting caspase-2-mediated apoptosis. PLoS ONE 2015, 10, e0118506. [CrossRef]

155. Nho, C.W.; Jeffery, E. The Synergistic Upregulation of Phase II Detoxification Enzymes by Glucosinolate Breakdown Products in Cruciferous Vegetables. Toxicol. Appl. Pharmacol. 2001, 174, 146-152. [CrossRef]

156. Saw, C.L.-L.; Cintrón, M.; Wu, T.-Y.; Guo, Y.; Huang, Y.; Jeong, W.-S.; Kong, A.-N.T. Pharmacodynamics of dietary phytochemical indoles I3C and DIM: Induction of Nrf2-mediated phase II drug metabolizing and antioxidant genes and synergism with isothiocyanates. Biopharm. Drug Dispos. 2011, 32, 289-300. [CrossRef] [PubMed]

157. Acharya, A.; Das, I.; Singh, S.; Saha, T. Chemopreventive properties of indole-3-carbinol, diindolylmethane and other constituents of cardamom against carcinogenesis. Recent Pat. Food Nutr. Agric. 2010, 2, 166-177. [CrossRef]

158. Ashok, B.T.; Chen, Y.; Liu, X.; Bradlow, H.L.; Mittelman, A.; Tiwari, R.K. Abrogation of Estrogen-Mediated Cellular and Biochemical Effects by Indole-3-Carbinol. Nutr. Cancer 2001, 41, 180-187. [CrossRef]

159. Ashok, B.T.; Chen, Y.G.; Liu, X.; Garikapaty, V.P.S.; Seplowitz, R.; Tschorn, J.; Roy, K.; Mittelman, A.; Tiwari, R.K. Multiple molecular targets of indole-3-carbinol, a chemopreventive anti-estrogen in breast cancer. Eur. J. Cancer Prev. 2002, 11 (Suppl. 2), S86-S93.

160. Meng, Q.; Yuan, F.; Goldberg, I.D.; Rosen, E.M.; Auborn, K.; Fan, S. Indole-3-Carbinol Is a Negative Regulator of Estrogen Receptor- $\alpha$ Signaling in Human Tumor Cells. J. Nutr. 2000, 130, 2927-2931. [CrossRef]

161. Li, Y.; Li, X.; Guo, B. Chemopreventive Agent 3,3'-Diindolylmethane Selectively Induces Proteasomal Degradation of Class I Histone Deacetylases. Cancer Res. 2010, 70, 646-654. [CrossRef]

162. Beaver, L.M.; Yu, T.-W.; Sokolowski, E.I.; Williams, D.E.; Dashwood, R.H.; Ho, E. 3,3'-Diindolylmethane, but not indole-3-carbinol, inhibits histone deacetylase activity in prostate cancer cells. Toxicol. Appl. Pharmacol. 2012, 263, 345-351. [CrossRef]

163. Li, Y.; VandenBoom, T.G.; Kong, D.; Wang, Z.; Ali, S.; Philip, P.A.; Sarkar, F.H. Up-regulation of miR-200 and let-7 by Natural Agents Leads to the Reversal of Epithelial-to-Mesenchymal Transition in Gemcitabine-Resistant Pancreatic Cancer Cells. Cancer Res. 2009, 69, 6704-6712. [CrossRef]

164. Li, Y.; VandenBoom, T.G.; Wang, Z.; Kong, D.; Ali, S.; Philip, P.A.; Sarkar, F.H. miR-146a Suppresses Invasion of Pancreatic Cancer Cells. Cancer Res. 2010, 70, 1486-1495. [CrossRef]

165. Kong, D.; Heath, E.; Chen, W.; Cher, M.; Powell, I.; Heilbrun, L.; Li, Y.; Ali, S.; Sethi, S.; Hassan, O. Erratum: Epigenetic silencing of miR-34a in human prostate cancer cells and tumor tissue specimens can be reversed by BR-DIM treatment. Am. J. Transl. Res. 2013, 6, 102-103.

166. Melkamu, T.; Zhang, X.; Tan, J.; Zeng, Y.; Kassie, F. Alteration of microRNA expression in vinyl carbamate-induced mouse lung tumors and modulation by the chemopreventive agent indole-3-carbinol. Carcinogenesis 2010, 31, 252-258. [CrossRef]

167. Jin, Y. 3,3'-Diindolylmethane inhibits breast cancer cell growth via miR-21-mediated Cdc25A degradation. Mol. Cell. Biochem. 2011, 358, 345-354. [CrossRef]

168. Busbee, P.B.; Nagarkatti, M.; Nagarkatti, P.S. Natural indoles, indole-3-carbinol and 3,3'-diindolymethane, inhibit $\mathrm{T}$ cell activation by staphylococcal enterotoxin $\mathrm{B}$ through epigenetic regulation involving HDAC expression. Toxicol. Appl. Pharmacol. 2014, 274, 7-16. [CrossRef]

169. Millimouno, F.M.; Dong, J.; Yang, L.; Li, J.; Li, X. Targeting apoptosis pathways in cancer and perspectives with natural compounds from mother nature. Cancer Prev. Res. 2014, 7, 1081-1107. [CrossRef]

170. Zuco, V.; Supino, R.; Righetti, S.C.; Cleris, L.; Marchesi, E.; Gambacorti-Passerini, C.; Formelli, F. Selective cytotoxicity of betulinic acid on tumor cell lines, but not on normal cells. Cancer Lett. 2002, 175, 17-25. [CrossRef]

171. Fulda, S.; Friesen, C.; Los, M.; Scaffidi, C.; Mier, W.; Benedict, M.; Nuã, G.; Krammer, P.H.; Peter, M.E.; Debatin, K. Betulinic Acid Triggers CD95 ( APO-1/Fas )—And p53-independent Apoptosis via Activation of Caspases in Neuroectodermal Tumors Activation of Caspases in Neuroectodermal Tumors. Cancer Res. 1997, 95, 4956-4964.

172. Liu, Y.; Zhang, X.; Liu, Z.; Wang, L.; Luo, L.; Wang, M.; Wang, Q.; Gao, D. Gold nanoshell-based betulinic acid liposomes for synergistic chemo-photothermal therapy. Nanomed. Nanotechnol. Biol. Med. 2017, 13, 1891-1900. [CrossRef] 
173. Mullauer, F.B.; Van Bloois, L.; Daalhuisen, J.B.; Ten Brink, M.S.; Storm, G.; Medema, J.P.; Schiffelers, R.M.; Kessler, J.H. Betulinic acid delivered in liposomes reduces growth of human lung and colon cancers in mice without causing systemic toxicity. Anticancer Drugs 2011, 22, 223-233. [CrossRef]

174. Tan, J.; Karthivashan, G.; Arulselvan, P.; Fakurazi, S.; Hussein, M. Characterization and in vitro studies of the anticancer effect of oxidized carbon nanotubes functionalized with betulinic acid. Drug Des. Dev. Ther. 2014, 20, 2333-2343. [CrossRef]

175. Olaharski, A.J.; Rine, J.; Marshall, B.L.; Babiarz, J.; Zhang, L.; Verdin, E.; Smith, M.T. The flavoring agent dihydrocoumarin reverses epigenetic silencing and inhibits sirtuin deacetylases. PLoS Genet. 2005, 1, 0689-0694. [CrossRef]

176. Chen, C.C.; Huang, J.S.; Wang, T.H.; Kuo, C.H.; Wang, C.J.; Wang, S.H.; Leu, Y.L. Dihydrocoumarin, an HDAC inhibitor, increases DNA damage sensitivity by inhibiting Rad52. Int. J. Mol. Sci. 2017, 18, 2655. [CrossRef]

177. Seidel, C.; Schnekenburger, M.; Zwergel, C.; Gaascht, F.; Mai, A.; Dicato, M.; Kirsch, G.; Valente, S.; Diederich, M. Novel inhibitors of human histone deacetylases: Design, synthesis and bioactivity of 3-alkenoylcoumarines. Bioorg. Med. Chem. Lett. 2014, 24, 3797-3801. [CrossRef]

178. Abdizadeh, T.; Kalani, M.R.; Abnous, K.; Tayarani-Najaran, Z.; Khashyarmanesh, B.Z.; Abdizadeh, R.; Ghodsi, R.; Hadizadeh, F. Design, synthesis and biological evaluation of novel coumarin-based benzamides as potent histone deacetylase inhibitors and anticancer agents. Eur. J. Med. Chem. 2017, 132, 42-62. [CrossRef]

179. Wu, X.; Zhou, Q.; Xu, K. Are isothiocyanates potential anti-cancer drugs? Acta Pharmacol. Sin. 2009, 30, 501-512. [CrossRef]

180. Zhang, Y.; Munday, R.; Jobson, H.E.; Munday, C.M.; Lister, C.; Wilson, P.; Fahey, J.W.; Mhawech-Fauceglia, P. Induction of GST and NQO1 in Cultured Bladder Cells and in the Urinary Bladders of Rats by an Extract of Broccoli (Brassica oleracea italica) Sprouts. J. Agric. Food Chem. 2006, 54, 9370-9376. [CrossRef]

181. Nune, S.K.; Gunda, P.; Thallapally, P.K.; Lin, Y.-Y.; Forrest, M.L.; Berkland, C.J. Nanoparticles for biomedical imaging. Expert Opin. Drug Deliv. 2009, 6, 1175-1194. [CrossRef]

182. Khosroshahi, M.E.; Asemani, M. International Journal of Nanomaterials, Nanotechnology and Nanomedicine Synthesis, Characterization and Imaging of Fluorescine Isothiocyanate Conjugated Magnetite Nanoparticles in MCF 7 Breast Cancer Cell Lines. Int. J. Nanomater. Nanotechnol. Nanomed. 2017, 3, 44-50.

183. Encinas-Basurto, D.; Ibarra, J.; Juarez, J.; Burboa, M.G.; Barbosa, S.; Taboada, P.; Troncoso-Rojas, R.; Valdez, M.A. Poly(lactic-co-glycolic acid) nanoparticles for sustained release of allyl isothiocyanate: Characterization, in vitro release and biological activity. J. Microencapsul. 2017, 34, 231-242. [CrossRef]

184. Traka, M.; Gasper, A.V.; Smith, J.A.; Hawkey, C.J.; Bao, Y.; Mithen, R.F. Transcriptome analysis of human colon Caco-2 cells exposed to sulforaphane. J. Nutr. 2005, 135, 1865-1872. [CrossRef]

185. Meeran, S.M.; Patel, S.N.; Tollefsbol, T.O. Sulforaphane Causes Epigenetic Repression of hTERT Expression in Human Breast Cancer Cell Lines. PLoS ONE 2010, 5, e11457. [CrossRef]

186. Myzak, M.C.; Karplus, P.A.; Chung, F.-L.; Dashwood, R.H. A Novel Mechanism of Chemoprotection by Sulforaphane. Cancer Res. 2004, 64, 5767-5774. [CrossRef]

187. Myzak, M.C.; Hardin, K.; Wang, R.; Dashwood, R.H.; Ho, E. Sulforaphane inhibits histone deacetylase activity in BPH-1, LnCaP and PC-3 prostate epithelial cells. Carcinogenesis 2006, 27, 811-819. [CrossRef]

188. Pledgie-Tracy, A.; Sobolewski, M.D.; Davidson, N.E. Sulforaphane induces cell type-specific apoptosis in human breast cancer cell lines. Mol. Cancer Ther. 2007, 6, 1013-1021. [CrossRef]

189. Wong, C.P.; Hsu, A.; Buchanan, A.; Palomera-Sanchez, Z.; Beaver, L.M.; Houseman, E.A.; Williams, D.E.; Dashwood, R.H.; Ho, E. Effects of Sulforaphane and 3,3'-Diindolylmethane on Genome-Wide Promoter Methylation in Normal Prostate Epithelial Cells and Prostate Cancer Cells. PLoS ONE 2014, 9, e86787. [CrossRef]

190. Su, Z.Y.; Zhang, C.; Lee, J.H.; Shu, L.; Wu, T.Y.; Khor, T.O.; Conney, A.H.; Lu, Y.P.; Kong, A.N.T. Requirement and epigenetics reprogramming of Nrf2 in suppression of tumor promoter TPA-induced mouse skin cell transformation by sulforaphane. Cancer Prev. Res. 2014, 7, 319-329. [CrossRef]

191. Myzak, M.C.; Dashwood, W.M.; Orner, G.A.; Ho, E.; Dashwood, R.H. Sulforaphane inhibits histone deacetylase in vivo and suppresses tumorigenesis in Apc min mice. FASEB J. 2006, 20, 506-508. [CrossRef]

192. Mileo, A.M.; Miccadei, S. Polyphenols as Modulator of Oxidative Stress in Cancer Disease: New Therapeutic Strategies. Oxid. Med. Cell. Longev. 2016, 2016, 6475624. [CrossRef] 
193. Gao, L.; Cheng, D.; Yang, J.; Wu, R.; Li, W.; Kong, A.-N. Sulforaphane epigenetically demethylates the CpG sites of the miR-9-3 promoter and reactivates miR-9-3 expression in human lung cancer A549 cells. J. Nutr. Biochem. 2018, 56, 109-115. [CrossRef]

194. Beaver, L.M.; Löhr, C.V.; Clarke, J.D.; Glasser, S.T.; Watson, G.W.; Wong, C.P.; Zhang, Z.; Williams, D.E.; Dashwood, R.H.; Shannon, J. Broccoli Sprouts Delay Prostate Cancer Formation and Decrease Prostate Cancer Severity with a Concurrent Decrease in HDAC3 Protein Expression in Transgenic Adenocarcinoma of the Mouse Prostate (TRAMP) Mice. Curr. Dev. Nutr. 2018, 2, nzy002. [CrossRef]

195. Myzak, M.C.; Tong, P.; Dashwood, W.-M.; Dashwood, R.H.; Ho, E. Sulforaphane retards the growth of human PC-3 xenografts and inhibits HDAC activity in human subjects. Exp. Biol. Med. 2007, 232, 227-234.

196. Jadhav, U.; Ezhilarasan, R.; Vaughn, S.F.; Berhow, M.A.; Mohanam, S. Dietary isothiocyanate iberin inhibits growth and induces apoptosis in human glioblastoma cells. J. Pharmacol. Sci. 2007, 103, 247-251. [CrossRef]

197. Jakubikova, J.; Bao, Y.; Bodo, J.; Sedlak, J. Isothiocyanate iberin modulates phase II enzymes, posttranslational modification of histones and inhibits growth of Caco-2 cells by inducing apoptosis. Neoplasma 2006, 53, 463-470.

198. Kore, A.M.; Jeffery, E.H.; Wallig, M.A. Effects of 1-isothiocyanato-3-(methylsulfinyl)-propane on xenobiotic metabolizing enzymes in rats. Food Chem. Toxicol. 1993, 31, 723-729. [CrossRef]

199. Wang, S.; Cheng, L.; Liu, Y.; Wang, J.; Jiang, W. Indole-3-Carbinol (I3C) and its Major Derivatives: Their Pharmacokinetics and Important Roles in Hepatic Protection. Curr. Drug Metab. 2016, 17, 401-409. [CrossRef]

200. Fan, S.; Meng, Q.; Auborn, K.; Carter, T.; Rosen, E.M. BRCA1 and BRCA2 as molecular targets for phytochemicals indole-3-carbinol and genistein in breast and prostate cancer cells. Br. J. Cancer 2006, 94, 407-426. [CrossRef]

201. White, A.I.; Jenkins, G.L. Salvia Carnosa (Dougl.). I-A Phytochemical Study**Abstracted from a part of the thesis presented to the Graduate Faculty of the University of Minnesota by Allen I. White in partial fulfilment of the requirements for the degree of Doctor of Philosophy. J. Am. Pharm. Assoc. 1942, 31, 33-37. [CrossRef]

202. Brieskorn, C.H.; Fuchs, A.; Bredenberg, J.B.S.; McChesney, J.D.; Wenkert, E. The Structure of Carnosol. J. Org. Chem. 1964, 29, 2293-2298. [CrossRef]

203. Chun, K.-S.; Kundu, J.K.J.; Chae, I.G.; Kundu, J.K.J. Carnosol: A Phenolic Diterpene With Cancer Chemopreventive Potential. J. Cancer Prev. 2014, 19, 103-110. [CrossRef]

204. Huang, M.T.; Ho, C.T.; Wang, Z.Y.; Ferraro, T.; Lou, Y.R.; Stauber, K.; Ma, W.; Georgiadis, C.; Laskin, J.D.; Conney, A.H. Inhibition of skin tumorigenesis by rosemary and its constituents carnosol and ursolic acid. Cancer Res. 1994, 54, 701-708.

205. Samarghandian, S.; Azimi-Nezhad, M.; Farkhondeh, T. Anti-Carcinogenic Effects of Carnosol-An Updated Review. Curr. Drug Discov. Technol. 2018, 15, 32-40. [CrossRef]

206. Giacomelli, C.; Daniele, S.; Natali, L.; Iofrida, C.; Flamini, G.; Braca, A.; Trincavelli, M.L.; Martini, C. Carnosol controls the human glioblastoma stemness features through the epithelial-mesenchymal transition modulation and the induction of cancer stem cell apoptosis. Sci. Rep. 2017, 7, 15174. [CrossRef]

207. Wang, L.; Zhang, Y.; Liu, K.; Chen, H.; Yang, R.; Ma, X.; Kim, H.-G.; Bode, A.M.; Kim, D.J.; Dong, Z. Carnosol suppresses patient-derived gastric tumor growth by targeting RSK2. Oncotarget 2018, 9, 34200. [CrossRef]

208. Singletary, K.; MacDonald, C.; Wallig, M. Inhibition by rosemary and carnosol of 7,12-dimethylbenz[a]anthracene (DMBA)-induced rat mammary tumorigenesis and in vivo DMBA-DNA adduct formation. Cancer Lett. 1996, 104, 43-48. [CrossRef]

209. Vergara, D.; Simeone, P.; Toraldo, D.; Del Boccio, P.; Vergaro, V.; Leporatti, S.; Pieragostino, D.; Tinelli, A.; De Domenico, S.; Alberti, S. Resveratrol downregulates Akt/GSK and ERK signalling pathways in OVCAR-3 ovarian cancer cells. Mol. Biosyst. 2012, 8, 1078-1087. [CrossRef]

210. Justo, O.R.; Simioni, P.U.; Gabriel, D.L.; Tamashiro WM DS, C.; Rosa PD, T.V.; Moraes Â, M. Evaluation of in vitro anti-inflammatory effects of crude ginger and rosemary extracts obtained through supercritical CO2 extraction on macrophage and tumor cell line: The influence of vehicle type. BMC Complement. Altern. Med. 2015, 15, 390. [CrossRef]

211. Frémont, L. Biological effects of resveratrol. Life Sci. 2000, 66, 663-673. [CrossRef]

212. Wang, Y.; Catana, F.; Yang, Y.; Roderick, R.; Van Breemen, R.B. An LC-MS Method for Analyzing Total Resveratrol in Grape Juice, Cranberry Juice, and in Wine. J. Agric. Food Chem. 2002, 50, 431-435. [CrossRef] 
213. Lyons, M.M.; Yu, C.; Toma, R.B.; Cho, S.Y.; Reiboldt, W.; Lee, J.; Van Breemen, R.B. Resveratrol in Raw and Baked Blueberries and Bilberries. J. Agric. Food Chem. 2003, 51, 5867-5870. [CrossRef]

214. Tokuşoğlu, Ö.; Ünal, M.K.; Yemiş, F. Determination of the Phytoalexin Resveratrol (3,5,4'-Trihydroxystilbene) in Peanuts and Pistachios by High-Performance Liquid Chromatographic Diode Array (HPLC-DAD) and Gas Chromatography-Mass Spectrometry (GC-MS). J. Agric. Food Chem. 2005, 53, 5003-5009. [CrossRef]

215. Siemann, E.H.; Creasy, L.L. Concentration of the Phytoalexin Resveratrol in Wine. Am. J. Enol. Vitic. 1992, $43,49-52$.

216. Berman, A.Y.; Motechin, R.A.; Wiesenfeld, M.Y.; Holz, M.K. The therapeutic potential of resveratrol: a review of clinical trials. NPJ Precis. Oncol. 2017, 1, 35. [CrossRef]

217. Varoni, E.M.; Faro, A.F.L.; Sharifi-Rad, J.; Iriti, M. Anticancer Molecular Mechanisms of Resveratrol. Front. Nutr. 2016, 3, 8. [CrossRef]

218. Kulkarni, S.S.; Cantó, C. The molecular targets of resveratrol. Biochim. et Biophys. Acta (BBA) - Mol. Basis Dis. 2015, 1852, 1114-1123. [CrossRef]

219. Sajish, M.; Schimmel, P. A human tRNA synthetase is a potent PARP1-activating effector target for resveratrol. Nature 2015, 519, 370. [CrossRef]

220. Farhan, M.; Ullah, M.F.; Faisal, M.; Farooqi, A.A.; Sabitaliyevich, U.Y.; Biersack, B.; Ahmad, A. Differential Methylation and Acetylation as the Epigenetic Basis of Resveratrol's Anticancer Activity. Medicines 2019, 6, 24. [CrossRef]

221. Dhar, S.; Kumar, A.; Rimando, A.M.; Zhang, X.; Levenson, A.S. Resveratrol and pterostilbene epigenetically restore PTEN expression by targeting oncomiRs of the miR-17 family in prostate cancer. Oncotarget 2015, 6, 27214-27226. [CrossRef] [PubMed]

222. Azimi, A.; Hagh, M.F.; Talebi, M.; Yousefi, B.; Hossein pour feizi, A.A.; Baradaran, B.; Movassaghpour, A.A.; Shamsasenjan, K.; Khanzedeh, T.; Ghaderi, A.H. Time-and Concentration-Dependent Effects of Resveratrol on miR 15a and miR16-1 Expression and Apoptosis in the CCRF-CEM Acute Lymphoblastic Leukemia Cell Line. Asian Pac. J. Cancer Prev. 2015, 16, 6463-6468. [CrossRef] [PubMed]

223. Qin, W.; Zhang, K.; Clarke, K.; Weiland, T.; Sauter, E.R. Methylation and miRNA Effects of Resveratrol on Mammary Tumors vs. Normal Tissue. Nutr. Cancer 2014, 66, 270-277. [CrossRef] [PubMed]

224. Summerlin, N.; Soo, E.; Thakur, S.; Qu, Z.; Jambhrunkar, S.; Popat, A. Resveratrol nanoformulations: Challenges and opportunities. Int. J. Pharm. 2015, 479, 282-290. [CrossRef] [PubMed]

225. Krüger, S.; Bergin, A.; Morlock, G.E. Effect-directed analysis of ginger (Zingiber officinale) and its food products, and quantification of bioactive compounds via high-performance thin-layer chromatography and mass spectrometry. Food Chem. 2018, 243, 258-268. [CrossRef] [PubMed]

226. Zadeh, J.B.; Kor, N.M. Physiological and pharmaceutical effects of Ginger (Zingiber officinale Roscoe) as a valuable medicinal plant. Eur. J. Exp. Biol. 2014, 4, 87-90.

227. Chrubasik, S.; Pittler, M.H.; Roufogalis, B.D. Zingiberis rhizoma: A comprehensive review on the ginger effect and efficacy profiles. Phytomedicine 2005, 12, 684-701. [CrossRef]

228. Ali, B.H.; Blunden, G.; Tanira, M.O.; Nemmar, A. Some phytochemical, pharmacological and toxicological properties of ginger (Zingiber officinale Roscoe): A review of recent research. Food Chem. Toxicol. 2008, 46, 409-420. [CrossRef]

229. Swapna Sonale, R.; Kadimi, U.S. Characterization of gingerol analogues in supercritical carbon dioxide (SC CO2) extract of ginger (Zingiber officinale, R.,). J. Food Sci. Technol. 2014, 51, 3383-3389. [CrossRef]

230. Kim, S.O.; Kundu, J.K.; Shin, Y.K.; Park, J.H.; Cho, M.H.; Kim, T.Y.; Surh, Y.J. [6]-Gingerol inhibits COX-2 expression by blocking the activation of 338 MAP kinase and NF- $\mathrm{kB}$ in phorbol ester-stimulated mouse skin. Oncogene 2005, 24, 2558-2567. [CrossRef]

231. Surh, Y.J. Anti-tumor promoting potential of selected spice ingredients with antioxidative and anti-inflammatory activities: A short review. Food Chem. Toxicol. 2002, 40, 1091-1097. [CrossRef]

232. Kim, E.C.; Min, J.K.; Kim, T.Y.; Lee, S.J.; Yang, H.O.; Han, S.; Kim, Y.M.; Kwon, Y.G. [6]-Gingerol, a pungent ingredient of ginger, inhibits angiogenesis in vitro and in vivo. Biochem. Biophys. Res. Commun. 2005, 335, 300-308. [CrossRef] [PubMed]

233. Wang, Q.; Wei, Q.; Yang, Q.; Cao, X.; Li, Q.; Shi, F.; Tong, S.S.; Feng, C.; Yu, Q.; Yu, J. A novel formulation of [6]-gingerol: Proliposomes with enhanced oral bioavailability and antitumor effect. Int. J. Pharm. 2018, 535, 308-315. [CrossRef] [PubMed] 
234. Rastogi, N.; Gara, R.K.; Trivedi, R.; Singh, A.; Dixit, P.; Maurya, R.; Duggal, S.; Bhatt, M.L.B.; Singh, S.; Mishra, D.P. (6)-Gingerolinduced myeloid leukemia cell death is initiated by reactive oxygen species and activation of miR-27b expression. Free Radic. Biol. Med. 2014, 68, 288-301. [CrossRef] [PubMed]

235. Lee, H.S.; Seo, E.Y.; Kang, N.E.; Kim, W.K. [6]-Gingerol inhibits metastasis of MDA-MB-231 human breast cancer cells. J. Nutr. Biochem. 2008, 19, 313-319. [CrossRef] [PubMed]

236. Shukla, Y.; Prasad, S.; Tripathi, C.; Singh, M.; George, J.; Kalra, N. In vitro and in vivo modulation of testosterone mediated alterations in apoptosis related proteins by [6]-gingerol. Mol. Nutr. Food Res. 2007, 51, 1492-1502. [CrossRef] [PubMed]

237. Weng, C.J.; Wu, C.F.; Huang, H.W.; Ho, C.T.; Yen, G.C. Anti-invasion effects of 6-shogaol and 6-gingerol, two active components in ginger, on human hepatocarcinoma cells. Mol. Nutr. Food Res. 2010, 54, 1618-1627. [CrossRef] [PubMed]

238. Lin, C.B.; Lin, C.C.; Tsay, G.J. 6-gingerol inhibits growth of colon cancer cell LoVo via induction of G2/M arrest. Evid.-Based Complement. Altern. Med. 2012, 2012, 326096. [CrossRef] [PubMed]

239. Lee, D.H.; Kim, D.W.; Jung, C.H.; Lee, Y.J.; Park, D. Gingerol sensitizes TRAIL-induced apoptotic cell death of glioblastoma cells. Toxicol. Appl. Pharmacol. 2014, 279, 253-265. [CrossRef] [PubMed]

240. Park, Y.J.; Wen, J.; Bang, S.; Park, S.W.; Song, S.Y. [6]-Gingerol Induces Cell Cycle Arrest and Cell Death of Mutant p53-expressing Pancreatic Cancer Cells. Yonsei Med. J. 2006, 47, 688-697. [CrossRef]

241. Oyagbemi, A.A.; Saba, A.B.; Azeez, O.I. Molecular targets of [6]-gingerol: Its potential roles in cancer chemoprevention. BioFactors 2010, 36, 169-178. [CrossRef] [PubMed]

242. Lee, T.Y.; Lee, K.C.; Chen, S.Y.; Chang, H.H. 6-Gingerol inhibits ROS and iNOS through the suppression of PKC- $\alpha$ and NF- $\mathrm{kB}$ pathways in lipopolysaccharide-stimulated mouse macrophages. Biochem. Biophys. Res. Commun. 2009, 382, 134-139. [CrossRef] [PubMed]

243. Chakraborty, D.; Bishayee, K.; Ghosh, S.; Biswas, R.; Kumar Mandal, S.; Rahman Khuda-Bukhsh, A. [6]-Gingerol induces caspase 3 dependent apoptosis and autophagy in cancer cells: Drug-DNA interaction and expression of certain signal genes in HeLa cells. Eur. J. Pharmacol. 2012, 694, 20-29. [CrossRef] [PubMed]

244. Nigam, N.; George, J.; Srivastava, S.; Roy, P.; Bhui, K.; Singh, M.; Shukla, Y. Induction of apoptosis by [6]-gingerol associated with the modulation of p53 and involvement of mitochondrial signaling pathway in B[a]P-induced mouse skin tumorigenesis. Cancer Chemother. Pharmacol. 2010, 65, 687-696. [CrossRef] [PubMed]

245. Bode, A.M.; Ma, W.Y.; Surh, Y.J.; Dong, Z. Inhibition of epidermal growth factor-induced cell transformation and activator protein 1 activation by [6]-gingerol. Cancer Res. 2001, 61, 850-853. [PubMed]

246. Citronberg, J.; Bostick, R.; Ahearn, T.; Turgeon, D.K.; Ruffin, M.T.; Djuric, Z.; Sen, A.; Brenner, D.E.; Zick, S.M. Effects of ginger supplementation on cell-cycle biomarkers in the normal-appearing colonic mucosa of patients at increased risk for colorectal cancer: Results from a pilot, randomized, and controlled trial. Cancer Prev. Res. 2013, 6, 271-281. [CrossRef] [PubMed]

247. Plengsuriyakarn, T.; Viyanant, V.; Eursitthichai, V.; Picha, P.; Kupradinun, P.; Itharat, A.; Na-Bangchang, K. Anticancer activities against cholangiocarcinoma, toxicity and pharmacological activities of Thai medicinal plants in animal models. BMC Complement. Altern. Med. 2012, 12, 23. [CrossRef]

248. Habib, S.H.M.; Makpol, S.; Hamid, N.A.A.; Das, S.; Ngah, W.Z.W.; Yusof, Y.A.M. Ginger extract (Zingiber officinale) has anti-cancer and anti-inflammatory effects on ethionine-induced hepatoma rats. Clinics 2008, 63, 807-813. [CrossRef]

249. Prasad, S.; Tyagi, A.K. Ginger and its constituents: Role in prevention and treatment of gastrointestinal cancer. Gastroenterol. Res. Pract. 2015, 2015, 142979. [CrossRef]

250. Ko, J.K.; Leung, C.C. Ginger extract and polaprezinc exert gastroprotective actions by anti-oxidant and growth factor modulating effects in rats. J. Gastroenterol. Hepatol. 2010, 25, 1861-1869. [CrossRef]

251. Manatunga, D.C.; de Silva, R.M.; de Silva, K.M.N.; de Silva, N.; Bhandari, S.; Yap, Y.K.; Costha, N.P. $\mathrm{pH}$ responsive controlled release of anti-cancer hydrophobic drugs from sodium alginate and hydroxyapatite bi-coated iron oxide nanoparticles. Eur. J. Pharm. Biopharm. 2017, 117, 29-38. [CrossRef] [PubMed]

252. Deol, P.K.; Kaur, I.P. Improving the therapeutic efficiency of ginger extract for treatment of colon cancer using a suitably designed multiparticulate system. J. Drug Target. 2013, 21, 855-865. [CrossRef] [PubMed]

253. Arora, S.; Singh, S.; Piazza, G.A.; Contreras, C.M.; Panyam, J.; Singh, A.P. Honokiol: A novel natural agent for cancer prevention and therapy. Curr. Mol. Med. 2012, 12, 1244-1252. [CrossRef] [PubMed] 
254. Kong, Z.-L.; Tzeng, S.-C.; Liu, Y.-C. Cytotoxic neolignans: An SAR study. Bioorg. Med. Chem. Lett. 2005, 15, 163-166. [CrossRef] [PubMed]

255. Guillermo-Lagae, R.; Santha, S.; Thomas, M.; Zoelle, E.; Stevens, J.; Kaushik, R.S.; Dwivedi, C. Antineoplastic Effects of Honokiol on Melanoma. Biomed. Res. Int. 2017, 2017, 5496398. [CrossRef] [PubMed]

256. Mannal, P.W.; Schneider, J.; Tangada, A.; McDonald, D.; McFadden, D.W. Honokiol produces anti-neoplastic effects on melanoma cells in vitro. J. Surg. Oncol. 2011, 104, 260-264. [CrossRef]

257. Arora, S.; Bhardwaj, A.; Srivastava, S.K.; Singh, S.; McClellan, S.; Wang, B.; Singh, A.P. Honokiol arrests cell cycle, induces apoptosis, and potentiates the cytotoxic effect of gemcitabine in human pancreatic cancer cells. PLOS ONE 2011, 6, e21573. [CrossRef]

258. Chilampalli, C.; Guillermo, R.; Kaushik, R.S.; Young, A.; Chandrasekher, G.; Fahmy, H.; Dwivedi, C. Honokiol, a chemopreventive agent against skin cancer, induces cell cycle arrest and apoptosis in human epidermoid A431 cells. Exp. Biol. Med. 2011, 236, 1351-1359. [CrossRef]

259. Leeman-Neill, R.J.; Cai, Q.; Joyce, S.C.; Thomas, S.M.; Bhola, N.E.; Neill, D.B.; Arbiser, J.L.; Grandis, J.R. Honokiol inhibits epidermal growth factor receptor signaling and enhances the antitumor effects of epidermal growth factor receptor inhibitors. Clin. Cancer Res. 2010, 16, 2571-2579. [CrossRef]

260. Xu, D.; Lu, Q.; Hu, X. Down-regulation of P-glycoprotein expression in MDR breast cancer cell MCF-7/ADR by honokiol. Cancer Lett. 2006, 243, 274-280. [CrossRef]

261. Wang, X.; Duan, X.; Yang, G.; Zhang, X.; Deng, L.; Zheng, H.; Deng, C.; Wen, J.; Wang, N.; Peng, C. Honokiol crosses BBB and BCSFB, and inhibits brain tumor growth in rat $9 \mathrm{~L}$ intracerebral gliosarcoma model and human U251 xenograft glioma model. PLoS ONE 2011, 6, e18490. [CrossRef]

262. Woodbury, A.; Yu, S.P.; Wei, L.; García, P. Neuro-modulating effects of honokiol: A review. Front. Neurol. 2013, 4, 130. [CrossRef]

263. Godugu, C.; Doddapaneni, R.; Singh, M. Honokiol nanomicellar formulation produced increased oral bioavailability and anticancer effects in triple negative breast cancer (TNBC). Colloids Surf. B Biointerfaces 2017, 153, 208-219. [CrossRef]

264. Frydoonfar, H.R.; McGrath, D.R.; Spigelman, A.D. The variable effect on proliferation of a colon cancer cell line by the citrus fruit flavonoid Naringenin. Color. Dis. 2003, 5, 149-152. [CrossRef]

265. Manthey, J.A.; Guthrie, N. Antiproliferative activities of citrus flavonoids against six human cancer cell lines. J. Agric. Food Chem. 2002, 50, 5837-5843. [CrossRef]

266. Harmon, A.W.; Patel, Y.M. Naringenin Inhibits Glucose Uptake in MCF-7 Breast Cancer Cells: A Mechanism for Impaired Cellular Proliferation. Breast Cancer Res. Treat. 2004, 85, 103-110. [CrossRef]

267. Harmon, A.W.; Patel, Y.M. Naringenin inhibits phosphoinositide 3-kinase activity and glucose uptake in 3T3-L1 adipocytes. Biochem. Biophys. Res. Commun. 2003, 305, 229-234. [CrossRef]

268. Galluzzo, P.; Ascenzi, P.; Bulzomi, P.; Marino, M. The Nutritional Flavanone Naringenin Triggers Antiestrogenic Effects by Regulating Estrogen Receptor $\alpha$-Palmitoylation. Endocrinology 2008, 149, 2567-2575. [CrossRef]

269. Zhang, F.Y.; Du, G.J.; Zhang, L.; Zhang, C.L.; Lu, W.L.; Liang, W. Naringenin Enhances the Anti-Tumor Effect of Doxorubicin Through Selectively Inhibiting the Activity of Multidrug Resistance-Associated Proteins but not P-glycoprotein. Pharm. Res. 2009, 26, 914-925. [CrossRef]

270. Krishnakumar, N.; Sulfikkarali, N.; RajendraPrasad, N.; Karthikeyan, S. Enhanced anticancer activity of naringenin-loaded nanoparticles in human cervical (HeLa) cancer cells. Biomed. Prev. Nutr. 2011, 1, $223-231$. [CrossRef]

271. Narumi, K.; Sonoda, J.I.; Shiotani, K.; Shigeru, M.; Shibata, M.; Kawachi, A.; Tomishige, E.; Sato, K.; Motoya, T. Simultaneous detection of green tea catechins and gallic acid in human serum after ingestion of green tea tablets using ion-pair high-performance liquid chromatography with electrochemical detection. J. Chromatogr. B Anal. Technol. Biomed. Life Sci. 2014, 945-946, 147-153. [CrossRef]

272. Song, Y.; Sun, H.; Zhang, A.; Yan, G.; Han, Y.; Wang, X. Plant-derived natural products as leads to anti-cancer drugs. J. Med. Plant Herb. Ther. Res. 2014, 2, 6-15.

273. Hosseinimehr, S.J.; Rostamnejad, M.; Ghaffari-rad, V. Epicatechin enhances anti-proliferative effect of bleomycin in ovarian cancer cell. Res. Mol. Med. 2013, 1, 24-27. [CrossRef]

274. Hagen, R.M.; Chedea, V.S.; Mintoff, C.P.; Bowler, E.; Morse, H.R.; Ladomery, M.R. Epigallocatechin-3-gallate promotes apoptosis and expression of the caspase 9a splice variant in PC3 prostate cancer cells. Int. J. Oncol. 2013, 43, 194-200. [CrossRef] 
275. Okabe, S.; Ochiai, Y.; Aida, M.; Park, K.; Kim, S.J.; Nomura, T.; Suganuma, M.F.H. Mechanistic aspects of green tea as a cancer preventive: Effect of components on human stomach cancer cell lines. Jpn. J. Cancer Res. 1999, 90, 733-739. [CrossRef]

276. Cao, J.; Han, J.; Xiao, H.; Qiao, J.; Han, M. Effect of tea polyphenol compounds on anticancer drugs in terms of anti-tumor activity, toxicology, and pharmacokinetics. Nutrients 2016, 8, 762. [CrossRef]

277. Rao, S.D.; Pagidas, K. Epigallocatechin-3-gallate, a Natural Polyphenol, Inhibits Cell Proliferation and Induces Apoptosis in Human Ovarian Cancer Cells. Anticancer Res. 2010, 30, 2519-2523.

278. Wang, C.; Luo, H.; Zhu, L.; Yang, F.; Chu, Z.; Tian, H.; Feng, M.; Zhao, Y.; Shang, P. Microgravity inhibition of lipopolysaccharide-induced tumor necrosis factor- $\alpha$ expression in macrophage cells. Inflamm. Res. 2014, 63, 91-98. [CrossRef]

279. Shankar, S.; Ganapathy, S.; Hingorani, S.R.; Srivastava, R.K. EGCG inhibits growth, invasion, angiogenesis and metastasis of pancreatic cancer. Front. Biosci. 2008, 13, 440-452. [CrossRef]

280. Sugihara, N.; Kuroda, N.; Watanabe, F.; Choshi, T.; Kamishikiryo, J.; Seo, M. Effects of Catechins and Their Related Compounds on Cellular Accumulation and Efflux Transport of Mitoxantrone in Caco-2 Cell Monolayers. J. Food Sci. 2017, 82, 1224-1230. [CrossRef]

281. Przystupski, D.; Michel, O.; Rossowska, J.; Kwiatkowski, S.; Saczko, J.; Kulbacka, J. The modulatory effect of green tea catechin on drug resistance in human ovarian cancer cells. Med. Chem. Res. 2019, 28, 657-667. [CrossRef]

282. Wang, W.; Ke, S.; Chen, G.; Gao, Q.; Wu, S.; Wang, S.; Zhou, J.; Yang, X.; Lu, Y.; Ma, D. Effect of lung resistance-related protein on the resistance to cisplatin in human ovarian cancer cell lines. Oncol. Rep. 2004, 12, 1365-1370. [CrossRef]

283. Kartalou, M.; Essigmann, J.M. Mechanisms of resistance to cisplatin. Mutat. Res. Fundam. Mol. Mech. Mutagen. 2001, 478, 23-43. [CrossRef]

284. Wang, X.; Jiang, P.; Wang, P.; Yang, C.S.; Wang, X. EGCG Enhances Cisplatin Sensitivity by Regulating Expression of the Copper and Cisplatin Influx Transporter CTR1 in Ovary Cancer. PLoS ONE 2015, 10, e0125402.

285. Fang, M.Z.; Wang, Y.; Ai, N.; Hou, Z.; Sun, Y.; Lu, H.; Welsh, W.; Yang, C.S. Tea polyphenol (-)-epigallocatechin-3-gallate inhibits DNA methyltransferase and reactivates methylation-silenced genes in cancer cell lines. Cancer Res. 2003, 63, 7563-7570.

286. Pandey, M.; Shukla, S.; Gupta, S. Promoter demethylation and chromatin remodeling by green tea polyphenols leads to re-expression of GSTP1 in human prostate cancer cells. Int. J. Cancer 2010, 126, 2520-2533. [CrossRef]

287. Thakur, V.S.; Gupta, K.; Gupta, S. Green tea polyphenols causes cell cycle arrest and apoptosis in prostate cancer cells by suppressing class I histone deacetylases. Carcinogenesis 2012, 33, 377-384. [CrossRef]

288. Li, Y.; Yuan, Y.-Y.; Meeran, S.M.; Tollefsbol, T.O. Synergistic epigenetic reactivation of estrogen receptor-alpha (ERalpha) by combined green tea polyphenol and histone deacetylase inhibitor in ERalpha-negative breast cancer cells. Mol. Cancer 2010, 9, 274. [CrossRef]

289. Nandakumar, V.; Vaid, M.; Katiyar, S.K. (-)-Epigallocatechin-3-gallate reactivates silenced tumor suppressor genes, Cip1/p21 and p16INK4a, by reducing DNA methylation and increasing histones acetylation in human skin cancer cells. Carcinogenesis 2011, 32, 537-544. [CrossRef]

290. Balasubramanian, S.; Adhikary, G.; Eckert, R.L. The Bmi-1 polycomb protein antagonizes the (-)-epigallocatechin-3-gallate-dependent suppression of skin cancer cell survival. Carcinogenesis 2010, 31, 496-503. [CrossRef]

291. Choudhury, S.R.; Balasubramanian, S.; Chew, Y.C.; Han, B.; Marquez, V.E.; Eckert, R.L. (-)-Epigallocatechin-3-gallate and DZNep reduce polycomb protein level via a proteasome-dependent mechanism in skin cancer cells. Carcinogenesis 2011, 32, 1525-1532. [CrossRef]

292. Deb, G.; Thakur, V.S.; Limaye, A.M.; Gupta, S. Epigenetic induction of tissue inhibitor of matrix metalloproteinase-3 by green tea polyphenols in breast cancer cells. Mol. Carcinog. 2015, 54, 485-499. [CrossRef]

293. Jha, M.; Aggarwal, R.; Jha, A.K.; Shrivastava, A. Natural Compounds: DNA Methyltransferase Inhibitors in Oral Squamous Cell Carcinoma. Appl. Biochem. Biotechnol. 2015, 177, 577-594. [CrossRef]

294. Khan, M.A.; Hussain, A.; Sundaram, M.K.; Alalami, U.; Gunasekera, D.; Ramesh, L.; Hamza, A.; Quraishi, U. (-)-Epigallocatechin-3-gallate reverses the expression of various tumor-suppressor genes by inhibiting 
DNA methyltransferases and histone deacetylases in human cervical cancer cells. Oncol. Rep. 2015, 33, 1976-1984. [CrossRef]

295. Zhou, X.-Q.; Xu, X.-N.; Li, L.; Ma, J.-J.; Zhen, E.-M.; Han, C.-B. Epigallocatechin-3-gallate inhibits the invasion of salivary adenoid cystic carcinoma cells by reversing the hypermethylation status of the RECK gene. Mol. Med. Rep. 2015, 12, 6031-6036. [CrossRef]

296. Chen, L.-L.; Han, W.-F.; Geng, Y.; Su, J.-S. A genome-wide study of DNA methylation modified by epigallocatechin-3-gallate in the CAL-27 cell line. Mol. Med. Rep. 2015, 12, 5886-5890. [CrossRef]

297. Li, Q.; Kakizaki, M.; Kuriyama, S.; Sone, T.; Yan, H.; Nakaya, N.; Mastuda-Ohmori, K.; Tsuji, I. Green tea consumption and lung cancer risk: The Ohsaki study. Br. J. Cancer 2008, 99, 1179-1184. [CrossRef]

298. Kang, H.; Rha, S.Y.; Oh, K.W.; Nam, C.M. Green tea consumption and stomach cancer risk: A meta-analysis. Epidemiol. Health 2010, 32, e2010001. [CrossRef]

299. Ni, C.-X.; Gong, H.; Liu, Y.; Qi, Y.; Jiang, C.-L.; Zhang, J.-P. Green Tea Consumption and the Risk of Liver Cancer: A Meta-Analysis. Nutr. Cancer 2017, 69, 211-220. [CrossRef]

300. Yang, G.; Zheng, W.; Xiang, Y.-B.; Gao, J.; Li, H.-L.; Zhang, X.; Gao, Y.-T.; Shu, X.-O. Green tea consumption and colorectal cancer risk: A report from the Shanghai Men's Health Study. Carcinogenesis 2011, 32, 1684-1688. [CrossRef]

301. Shrubsole, M.J.; Lu, W.; Chen, Z.; Shu, X.O.; Zheng, Y.; Dai, Q.; Cai, Q.; Gu, K.; Ruan, Z.X.; Gao, Y.-T. Drinking Green Tea Modestly Reduces Breast Cancer Risk. J. Nutr. 2009, 139, 310-316. [CrossRef]

302. Kurahashi, N.; Sasazuki, S.; Iwasaki, M.; Inoue, M.; Tsugane, S.; JPHC Study Group. Green Tea Consumption and Prostate Cancer Risk in Japanese Men: A Prospective Study. Am. J. Epidemiol. 2007, 167, 71-77. [CrossRef]

303. Tsao, A.S.; Liu, D.; Martin, J.; Tang, X.M.; Lee, J.J.; El-Naggar, A.K.; Wistuba, I.; Culotta, K.S.; Mao, L.; Gillenwater, A. Phase II Randomized, Placebo-Controlled Trial of Green Tea Extract in Patients with High-Risk Oral Premalignant Lesions. Cancer Prev. Res. 2009, 2, 931-941. [CrossRef]

304. Hakim, I.A.; Harris, R.B.; Brown, S.; Chow, H.-H.S.; Wiseman, S.; Agarwal, S.; Talbot, W. Effect of increased tea consumption on oxidative DNA damage among smokers: A randomized controlled study. J. Nutr. 2003, 133, 3303S-3309S. [CrossRef]

305. Luo, H.; Tang, L.; Tang, M.; Billam, M.; Huang, T.; Yu, J.; Wei, Z.; Liang, Y.; Wang, K.; Zhang, Z.-Q. Phase Ila chemoprevention trial of green tea polyphenols in high-risk individuals of liver cancer: Modulation of urinary excretion of green tea polyphenols and 8-hydroxydeoxyguanosine. Carcinogenesis 2006, 27, 262-268. [CrossRef]

306. Bettuzzi, S.; Brausi, M.; Rizzi, F.; Castagnetti, G.; Peracchia, G.; Corti, A. Chemoprevention of Human Prostate Cancer by Oral Administration of Green Tea Catechins in Volunteers with High-Grade Prostate Intraepithelial Neoplasia: A Preliminary Report from a One-Year Proof-of-Principle Study. Cancer Res. 2006, 66, 1234-1240. [CrossRef]

307. Sun, Q.; Cai, X.; Li, J.; Zheng, M.; Chen, Z.; Yu, C.-P. Green synthesis of silver nanoparticles using tea leaf extract and evaluation of their stability and antibacterial activity. Colloids Surfaces A Physicochem. Eng. Asp. 2014, 444, 226-231. [CrossRef]

308. Mukherjee, S.; Ghosh, S.; Das, D.K.; Chakraborty, P.; Choudhury, S.; Gupta, P.; Adhikary, A.; Dey, S.; Chattopadhyay, S. Gold-conjugated green tea nanoparticles for enhanced anti-tumor activities and hepatoprotection-Synthesis, characterization and in vitro evaluation. J. Nutr. Biochem. 2015, 26, 1283-1297. [CrossRef]

309. Nakhjavani, M.; Nikkhah, V.; Sarafraz, M.M.; Shoja, S.; Sarafraz, M. Green synthesis of silver nanoparticles using green tea leaves: Experimental study on the morphological, rheological and antibacterial behaviour. Heat Mass Transf. 2017, 53, 3201-3209. [CrossRef]

310. Wang, Y.-J.; Huang, Y.; Anreddy, N.; Zhang, G.-N.; Zhang, Y.-K.; Xie, M.; Lin, D.; Yang, D.-H.; Zhang, M.; Chen, Z.-S. Tea nanoparticle, a safe and biocompatible nanocarrier, greatly potentiates the anticancer activity of doxorubicin. Oncotarget 2016, 7, 5877-5891. [CrossRef]

311. Michel, O.; Przystupski, D.; Saczko, J.; Szewczyk, A.; Niedzielska, N.; Rossowska, J.; Kulbacka, J. The favourable effect of catechin in electrochemotherapy in human pancreatic cancer cells. Acta Biochim. Pol. 2018, 65, 173-184. [CrossRef]

312. Hsieh, C.-H.; Lu, C.-H.; Chen, W.-T.; Ma, B.-L.; Chao, C.-Y. Application of non-invasive low strength pulsed electric field to EGCG treatment synergistically enhanced the inhibition effect on PANC-1 cells. PLoS ONE 2017, 12, e0188885. [CrossRef] 
313. Moreira, L.L.; Dias, T.; Dias, L.G.; Rogão, M.; Da Silva, J.P.; Estevinho, L.M. Propolis influence on erythrocyte membrane disorder (hereditary spherocytosis): A first approach. Food Chem. Toxicol. 2011, 49, 520-526. [CrossRef]

314. Rzepecka-Stojko, A.; Kabała-Dzik, A.; Moździerz, A.; Kubina, R.; Wojtyczka, R.; Stojko, R.; Dziedzic, A.; Jastrzębska-Stojko, Ż.; Jurzak, M.; Buszman, E. Caffeic Acid Phenethyl Ester and Ethanol Extract of Propolis Induce the Complementary Cytotoxic Effect on Triple-Negative Breast Cancer Cell Lines. Molecules 2015, 20, 9242-9262. [CrossRef]

315. Murtaza, G.; Karim, S.; Akram, M.R.; Khan, S.A.; Azhar, S.; Mumtaz, A.; Bin Asad, M.H.H. Caffeic acid phenethyl ester and therapeutic potentials. Biomed. Res. Int. 2014, 2014, 145342. [CrossRef]

316. Jo, S.-Y.; Lee, N.; Hong, S.-M.; Jung, H.H.; Chae, S.-W. Caffeic Acid Phenethyl Ester Inhibits Diesel Exhaust Particle-Induced Inflammation of Human Middle Ear Epithelial Cells via NOX4 Inhibition. Ann. Otol. Rhinol. Laryngol. 2013, 122, 595-600. [CrossRef]

317. da Cunha, F.M.; Duma, D.; Assreuy, J.; Buzzi, F.C.; Niero, R.; Campos, M.M.; Calixto, J.B. Caffeic Acid Derivatives: In Vitro and In Vivo Anti-inflammatory Properties. Free Radic. Res. 2004, 38, 1241-1253. [CrossRef]

318. Borrelli, F.; Maffia, P.; Pinto, L.; Ianaro, A.; Russo, A.; Capasso, F.; Ialenti, A. Phytochemical compounds involved in the anti-inflammatory effect of propolis extract. Fitoterapia 2002, 73 (Suppl. 1), S53-S63. [CrossRef]

319. Hishikawa, K.; Nakaki, T.; Fujita, T. Oral Flavonoid Supplementation Attenuates Atherosclerosis Development in Apolipoprotein E-Deficient Mice. Arterioscler. Thromb. Vasc. Biol. 2004, 25, 442-446. [CrossRef]

320. Park, J.H.; Lee, J.K.; Kim, H.S.; Chung, S.T.; Eom, J.H.; Kim, K.A.; Chung, S.J.; Paik, S.Y.; Oh, H.Y. Immunomodulatory effect of caffeic acid phenethyl ester in Balb/c mice. Int. Immunopharmacol. 2004, 4, 429-436. [CrossRef]

321. Lee, K.J.; Choi, J.H.; Khanal, T.; Hwang, Y.P.; Chung, Y.C.; Jeong, H.G. Protective effect of caffeic acid phenethyl ester against carbon tetrachloride-induced hepatotoxicity in mice. Toxicology 2008, 248, 18-24. [CrossRef]

322. Ilhan, A.; Iraz, M.; Gurel, A.; Armutcu, F.; Akyol, O. Caffeic acid phenethyl ester exerts a neuroprotective effect on CNS against pentylenetetrazol-induced seizures in mice. Neurochem. Res. 2004, 29, 2287-2292. [CrossRef]

323. Orban, Z.; Mitsiades, N.; Burke, T.R.; Tsokos, M.; Chrousos, G.P. Caffeic acid phenethyl ester induces leukocyte apoptosis, modulates nuclear factor-kappa B and suppresses acute inflammation. Neuroimmunomodulation 2000, 7, 99-105. [CrossRef]

324. Chinery, R.; Beauchamp, R.D.; Shyr, Y.; Kirkland, S.C.; Coffey, R.J.; Morrow, J.D.; Mestre, J.R.; Grunberger, D.; Sacks, P.G.; Tanabe, T. Antioxidants reduce cyclooxygenase-2 expression, prostaglandin production, and proliferation in colorectal cancer cells. Cancer Res. 1998, 58, 2323-2327.

325. Lee, Y.-J.; Kuo, H.-C.; Chu, C.-Y.; Wang, C.-J.; Lin, W.-C.; Tseng, T.-H. Involvement of tumor suppressor protein p53 and p38 MAPK in caffeic acid phenethyl ester-induced apoptosis of C6 glioma cells. Biochem. Pharmacol. 2003, 66, 2281-2289. [CrossRef]

326. Kuo, H.-C.; Kuo, W.-H.; Lee, Y.-J.; Lin, W.-L.; Chou, F.-P.; Tseng, T.-H. Inhibitory effect of caffeic acid phenethyl ester on the growth of C6 glioma cells in vitro and in vivo. Cancer Lett. 2006, 234, 199-208. [CrossRef]

327. Sawicka, D.; Car, H.; Borawska, M.H.; Nikliński, J. The anticancer activity of propolis. Folia Histochem. Cytobiol. 2012, 500004, 25-37. [CrossRef]

328. McEleny, K.; Coffey, R.; Morrissey, C.; Fitzpatrick, J.M.; Watson, R.W.G. Caffeic acid phenethyl ester-induced PC-3 cell apoptosis is caspase-dependent and mediated through the loss of inhibitors of apoptosis proteins. BJU Int. 2004, 94, 402-406. [CrossRef]

329. Ozturk, G.; Ginis, Z.; Akyol, S.; Erden, G.; Gurel, A.; Akyol, O. The anticancer mechanism of caffeic acid phenethyl ester (CAPE): Review of melanomas, lung and prostate cancers. Eur. Rev. Med. Pharmacol. Sci. 2012, 16, 2064-2068.

330. Kudugunti, S.K.; Thorsheim, H.; Yousef, M.S.; Guan, L.; Moridani, M.Y. The metabolic bioactivation of caffeic acid phenethyl ester (CAPE) mediated by tyrosinase selectively inhibits glutathione S-transferase. Chem. Biol. Interact. 2011, 192, 243-256. [CrossRef]

331. Hwang, H.J.; Park, H.J.; Chung, H.-J.; Min, H.-Y.; Park, E.-J.; Hong, J.-Y.; Lee, S.K. Inhibitory effects of caffeic acid phenethyl ester on cancer cell metastasis mediated by the down-regulation of matrix metalloproteinase expression in human HT1080 fibrosarcoma cells. J. Nutr. Biochem. 2006, 17, 356-362. [CrossRef] 
332. Lee, W.J.; Zhu, B.T. Inhibition of DNA methylation by caffeic acid and chlorogenic acid, two common catechol-containing coffee polyphenols. Carcinogenesis 2006, 27, 269-277. [CrossRef]

333. Omene, C.; Kalac, M.; Wu, J.; Marchi, E.; Frenkel, K.; O'Connor, O.A. Propolis and its active component, Caffeic acid phenethyl ester (CAPE), modulate breast cancer therapeutic targets via an epigenetically mediated mechanism of action. J. Cancer Sci. Ther. 2013, 5, 334-342.

334. Pellerito, C.; Morana, O.; Ferrante, F.; Calvaruso, G.; Notaro, A.; Sabella, S.; Fiore, T. Synthesis, chemical characterization, computational studies and biological activity of new DNA methyltransferases (DNMTs) specific inhibitor. Epigenetic regulation as a new and potential approach to cancer therapy. J. Inorg. Biochem. 2015, 150, 18-27. [CrossRef]

335. Eanes, L.; Patel, Y.M. Inhibition of the MAPK pathway alone is insufficient to account for all of the cytotoxic effects of naringenin in MCF-7 breast cancer cells. Biochim. Open 2016, 3, 64-71. [CrossRef]

336. Frezza, M.; Garay, J.; Chen, D.; Cui, C.; Turos, E.; Dou, Q.P. Induction of tumor cell apoptosis by a novel class of $\mathrm{N}$-thiolated beta-lactam antibiotics with structural modifications at $\mathrm{N} 1$ and $\mathrm{C} 3$ of the lactam ring. Int. J. Mol. Med. 2008, 21, 689-695.

337. Kubina, R.; Kabała-Dzik, A.; Dziedzic, A.; Bielec, B.; Wojtyczka, R.D.; Bułdak, R.J.; Wyszyńska, M.; Stawiarska-Pięta, B.; Szaflarska-Stojko, E. The ethanol extract of polish propolis exhibits anti-proliferative and/or pro-apoptotic effect on HCT 116 colon cancer and Me45 Malignant melanoma cells in vitro conditions. Adv. Clin. Exp. Med. 2015, 24, 203-212. [CrossRef]

338. Patel, S. Emerging Adjuvant Therapy for Cancer: Propolis and its Constituents. J. Diet. Suppl. 2016, 13, $245-268$. [CrossRef]

339. Turan, I.; Demir, S.; Misir, S.; Kilinc, K.; Mentese, A.; Aliyazicioglu, Y.; Deger, O. Cytotoxic effect of Turkish propolis on liver, colon, breast, cervix and prostate cancer cell lines. Trop. J. Pharm. Res. 2015, 14, 777-782. [CrossRef]

340. Khan, T.; Gurav, P. PhytoNanotechnology: Enhancing delivery of plant based anti-cancer drugs. Front. Pharmacol. 2018, 8, 1002. [CrossRef]

341. Bhavana, V.; Sudharshan, S.J.S.; Madhu, D. Natural Anticancer Compounds and Their Derivatives in Clinical Trials; Springer: Singapore, 2018; ISBN 9789811082160.

342. Nguyen, M.M.; Ahmann, F.R.; Nagle, R.B.; Hsu, C.-H.; Tangrea, J.A.; Parnes, H.L.; Sokoloff, M.H.; Gretzer, M.B.; Chow, H.-H.S. Randomized, double-blind, placebo-controlled trial of polyphenon $\mathrm{E}$ in prostate cancer patients before prostatectomy: Evaluation of potential chemopreventive activities. Cancer Prev. Res. 2012, 5, 290-298. [CrossRef]

343. Reed, G.A.; Peterson, K.S.; Smith, H.J.; Gray, J.C.; Sullivan, D.K.; Mayo, M.S.; Crowell, J.A.; Hurwitz, A. A Phase I Study of Indole-3-Carbinol in Women: Tolerability and Effects. Cancer Epidemiol. Biomark. Prev. 2005, 14, 1953-1960. [CrossRef]

344. Lozanovski, V.J.; Houben, P.; Hinz, U.; Hackert, T.; Herr, I.; Schemmer, P. Pilot study evaluating broccoli sprouts in advanced pancreatic cancer (POUDER trial) - study protocol for a randomized controlled trial. Trials 2014, 15, 204. [CrossRef]

345. Gezici, S.; Şekeroğlu, N. Current Perspectives in the Application of Medicinal Plants Against Cancer: Novel Therapeutic Agents. Anticancer. Agents Med. Chem. 2019, 19, 101-111. [CrossRef]

346. Zhang, Y.; Xu, Q.; Lu, J.; Wang, P.; Zhang, H. Tea consumption and the incidence of cancer: A systematic review and meta-analysis of prospective observational studies. Eur. J. Cancer Prev. 2015, 24, 353-362. [CrossRef]

(C) 2019 by the authors. Licensee MDPI, Basel, Switzerland. This article is an open access article distributed under the terms and conditions of the Creative Commons Attribution (CC BY) license (http://creativecommons.org/licenses/by/4.0/). 